\title{
Spatial variability in oxygen and nutrient fluxes at the sediment-water interface on the continental shelf in the Gulf of Lions (NW Mediterranean)
}

\section{Variabilité spatiale des flux d'oxygène et de sels nutritifs à l'interface eau-sédiment dans le golfe du Lion (Méditerranée nord-occidentale)}

\author{
Lionel Denis $^{\mathrm{a}, *}$, Christian Grenz ${ }^{\mathrm{b}}$ \\ ${ }^{a}$ Université des sciences et technologies de Lille, station marine de Wimereux, UMR 8013 Elico 28, avenue Foch, BP 80, 62930 Wimereux, France \\ ${ }^{b}$ Centre d'océanologie de Marseille, station marine d'Endoume, UMR 6535 Lob rue de la batterie des Lions, 13007 Marseille, France
}

Received 4 October 2002; received in revised form 31 October 2002; accepted 18 November 2002

\begin{abstract}
The spatial variability of oxygen and dissolved nutrient exchanges across the sediment-water interface was studied on the continental shelf in the Gulf of Lions (NW Mediterranean Sea). Replicate sediment cores were sampled at nine stations (64-162 m depth) along two lines parallel to the coast during two cruises in March and June 1998. Sediment-water exchanges were measured using the core incubation technique. Surficial sediments, bottom water and interstitial water characteristics were also described. Fluxes of oxygen $\left(3.72-8.83 \mathrm{mmol} \mathrm{m}^{-2}\right.$ $\left.\mathrm{d}^{-1}\right)$, nitrate $\left(0.026-0.283 \mathrm{mmol} \mathrm{m} \mathrm{d}^{-2}\right)$, ammonium (-0.022 to $\left.0.204 \mathrm{mmol} \mathrm{m}^{-2} \mathrm{~d}^{-1}\right)$, nitrite $\left(-0.034\right.$ to $\left.0.002 \mathrm{mmol} \mathrm{m}^{-2} \mathrm{~d}^{-1}\right)$, phosphate $\left(-0.007\right.$ to $\left.0.029 \mathrm{mmol} \mathrm{m}^{-2} \mathrm{~d}^{-1}\right)$ and silicate $\left(0.504-1.656 \mathrm{mmol} \mathrm{m}^{-2} \mathrm{~d}^{-1}\right)$ were generally quite low. This has to be related to the oligotrophy of the Mediterranean Sea. Fluxes showed a weak spatial variability, and a significant correlation could be established between oxygen fluxes and the organic carbon content of surficial sediments. A general increase in ammonium, nitrate and phosphate release was also observed towards the coast and the mouth of the Rhône River. Nitrite uptake and silicate release showed high variability between cruises, and the change in silicate fluxes depended mainly on the location on the eastern or western part of the continental shelf.

Over the whole continental shelf, calculated sediment mineralization rate represents $342 \mathrm{kt} \mathrm{a}^{-1}$ of organic carbon. The annual release from the sediments approximates to $14.1 \mathrm{kt}$ dissolved inorganic nitrogen, $2.9 \mathrm{kt} \mathrm{P}$, and $165 \mathrm{kt}$ dissolved silica, which represent, respectively, an amount close to $5 \%, 7 \%$ and $28 \%$ of the nutrient requirements for primary production. When compared to nutrient inputs from the Rhône River, sediments appear to play a significant role in the biogeochemical cycles of the Gulf of Lions system, mainly for inorganic phosphorus and dissolved silica.
\end{abstract}

(C) 2003 Éditions scientifiques et médicales Elsevier SAS and Ifremer/CNRS/IRD. All rights reserved.

\section{Résumé}

Cette étude décrit la variabilité spatiale des échanges dissous à l'interface eau-sédiment dans le golfe du Lion. Des carottes sédimentaires ont été échantillonnées à neuf stations (64-162 m de profondeur) sur deux lignes parallèles à la côte, au cours de deux campagnes (mars et juin 1998). Les flux à l'interface eau-sédiment ont été mesurés par incubation de carottes. Des analyses complémentaires permettent de décrire les caractéristiques des sédiments superficiels, de l'eau de fond et de l'eau interstitielle. Les flux d'oxygène $\left(3,72-8,83 \mathrm{mmol} \mathrm{m}^{-2} \mathrm{~d}^{-1}\right)$, de nitrate $\left(0,026-0,283 \mathrm{mmol} \mathrm{m}^{-2} \mathrm{~d}^{-1}\right)$, d'ammonium $\left(-0,022\right.$ à $\left.0,204 \mathrm{mmol} \mathrm{m}^{-2} \mathrm{~d}^{-1}\right)$, de nitrite $\left(-0,034\right.$ à $\left.0,002 \mathrm{mmol} \mathrm{m}^{-2} \mathrm{~d}^{-1}\right)$, de phosphate $(-0,007$ à $\left.0,029 \mathrm{mmol} \mathrm{m}^{-2} \mathrm{~d}^{-1}\right)$ et de silicium dissous $\left(0,504\right.$ à $\left.1,656 \mathrm{mmol} \mathrm{m}^{-2} \mathrm{~d}^{-1}\right)$ sont généralement faibles, en raison de l'oligotrophie de la mer Méditerranée. Les échanges à l'interface eau-sédiment montrent une faible variabilité spatiale, et un lien a été établi entre les flux d'oxygène et le contenu en carbone organique des sédiments superficiels. Une augmentation générale du relargage d'ammonium, de nitrate et de

* Corresponding author.

E-mail address: lionel.denis@univ-lille1.fr (L. Denis). 
phosphate est également mise en évidence vers l'embouchure du Rhône. D’importants changements des flux de nitrites vers les sédiments ainsi que du relargage de silicate ont été observés entre les deux campagnes, avec pour ce dernier des différences majeures entre les zones situées à l'est et à l'ouest du golfe. Pour l'ensemble du plateau continental, les bilans à l'échelle du golfe du Lion correspondent à la minéralisation de $342 \mathrm{kt} \mathrm{a}^{-1}$ de carbone organique, et le relargage annuel de $14.1 \mathrm{kt}$ d'azote inorganique dissous, $2.9 \mathrm{kt} \mathrm{P}$, et $165 \mathrm{kt}$ de silice dissoute. Ces valeurs équivalent à 5\% DIN, 7\% P et 28\% DSi de la consommation par la production primaire, et sont plus élevées que les apports rhodaniens en ce qui concerne le phosphate et le silicium dissous.

(C) 2003 Éditions scientifiques et médicales Elsevier SAS and Ifremer/CNRS/IRD. All rights reserved.

Keywords: Sediment-water fluxes; Nutrients; Mineralization processes; NW Mediterranean; Continental shelf

Mots clés : Flux à l’interface eau-sédiment ; Sels nutritifs ; Minéralisation ; Méditerranée nord-occidentale ; Plateau continental

\section{Introduction}

Previous estimates showed that more than $80 \%$ of the global benthic mineralization takes place on continental margins (Middelburg et al., 1997), even if the surface area covered represents only $11 \%$ of the global ocean. This is not surprising as these systems are confluence zones between terrestrial, atmospheric and marine areas, and are generally characterized by a high productivity, mainly due to freshwater inputs and a tight coupling between pelagic and benthic systems. As a consequence, the vertical sink of organic material coupled with shallow water depth result in a large part of organic matter mineralization occurring in surficial sediments. Thus, continental margin sediments play an important role not only in carbon and nitrogen sinks (Walsh, 1991), but also in recycling processes of nutrients and carbon, fuelling primary production in the water column.

Surprisingly, despite the obvious importance of margin sediments in the global cycles of many elements and the wide area covered by the continental shelf in the Gulf of Lions, there have been only a few studies of elemental cycling in these sediments, whereas pelagic processes are quite well documented. This discrepancy was pointed out by TusseauVuillemin et al. (1998), who demonstrated the need for accurate quantification of dissolved inorganic nitrogen (DIN) fluxes at the sediment-water interface for a pelagic model in this area. Moreover, sediments have previously been shown to supply a major part of phytoplankton nutrient demand in shallow systems (Koop et al., 1990; Cowan and Boynton, 1996). For the NW Mediterranean Sea, benthic nutrient regeneration may be of prime importance, considering the oligotrophic status of this system and the nitrogen and/or phosphorus limitation of primary production (Conan, 1996; Diaz et al., 2001).

Most data concerning the benthic system in the Gulf of Lions were compiled in the frame of the Eros 2000 (European River Ocean Systems, 2000; Martin and Milliman, 1997) and Ecomarge program (Ecosystèmes de Marge continentale; Monaco et al., 1990), which basically focussed on freshwater and atmospheric inputs as well as transfer processes towards deep-sea sediments. A few sediment-water exchanges of oxygen and nutrients on the continental shelf were previously reported from five UE Eros 2000 cruises during the period 1987-1991. It is difficult to estimate from these data a budget for a given period due to the diversity in methodology (interstitial profiles, whole core incubation and benthic chambers), the different cruise periods and the various environments sampled (from near shore coastal to deepsea sediments).

In the following, we describe spatial variability of benthic exchange and mineralization rates on the continental shelf in the Gulf of Lions during two sampling periods. The aims of this study were (1) to determine whether a major horizontal gradient of mineralization rates exists from the mouth of the Rhône River to more offshore regions, and (2) quantify the role played by sediments in the global functioning of the continental shelf of the Gulf of Lions. This work was conducted in the frame of the Moogli cruises (Modélisation et Observation du golfe du Lion), a component of the Programme national en Environnement côtier (PNEC - chantier golfe du Lion) organized to establish an annual budget of carbon and biogenic elements for this area.

\section{Material and methods}

\subsection{Site description}

The site studied is the large continental shelf (up to $70 \mathrm{~km}$ width, total area $\approx 16000 \mathrm{~km}^{2}$ ) located in the northwestern part of the Mediterranean Sea and called the Gulf of Lions. The general water mass circulation on the continental shelf is complex but well documented, and basically driven by the cyclonic Northern Current (Millot, 1987). The shelf break is bordered by the deeper branch of the northern current, which makes incursions onto the shelf, providing exchanges with the open sea (Millot, 1990). With a mean discharge around $1690 \mathrm{~m}^{3} \mathrm{~s}^{-1}$, the Rhône River is a large source of nutrients and particulate matter to the Gulf of Lions (Leveau and Coste, 1987; Moutin et al., 1998). These inputs are transported to the southwest by an along-shore circulation (Pinazo et al., 1996), supporting about half the annual primary production (Morel et al., 1990).

The stations visited during the cruises in March and June 1998 are located along two lines parallel to the French coast (inner shelf and outer shelf stations) Fig. 1. Table 1. Most of the stations were located at depths ranging from 91 to $102 \mathrm{~m}$, which is the common depth of the continental shelf in the 


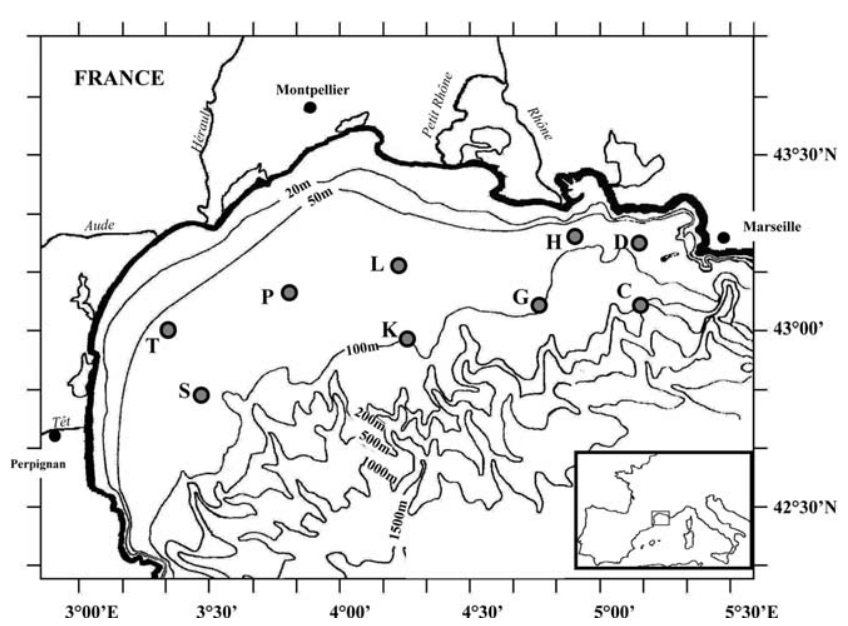

Fig. 1. Location of the stations sampled during the March and June cruises on the continental shelf of the NW Mediterranean Sea.

Gulf of Lions. Only two stations were located outside this range, shallower on the continental shelf (Station T: $64 \mathrm{~m}$ ) and deeper on the adjacent upper slope (Station C: $162 \mathrm{~m}$ ).

\subsection{Sampling and incubation device}

Sediment samples were obtained with a sediment multicorer Mark VI (Bowers and Connelly) using Perspex cores (i.d.: $15 \mathrm{~cm}$, length: $50 \mathrm{~cm}$ ), sampling around $30 \mathrm{~cm}$ of sediments and $20 \mathrm{~cm}$ of overlying water $(3.51)$. The large diameter of the cores allowed taking into account a part of the spatial heterogeneity of macrobenthic and smaller organisms, which is necessary to obtain an accurate measurement of fluxes (Christensen et al., 1984). Three or four sediment cores (total area sampled: 530-707 $\mathrm{cm}^{2}$ ) were collected at each station, and retrieved cores generally presented a regular sediment-water interface, delicate biogenic microstructures and clear overlying water. After visual inspection, the cores were immediately sealed and placed in dark refrigerated cabinets at in situ temperature as recorded by CTD (Seabird Model 9117). For each core retrieval, bottom water samples (ca. 201 ) were taken with a rosette sampler approximately $5 \mathrm{~m}$ above the sediment. The bottom water was gently transferred to an inflatable reserve tank excluding bubbles and stored under the same conditions as the incubated cores.
The incubation device is detailed in Denis et al. (2001). Briefly, overlying water was continuously homogenized with a rotating floating magnet fixed to the upper cap (Cowan et al., 1996). Each core was linked by tubing to the inflatable reserve tank filled with bottom water, and the volume removed in each core tube was replaced with bottom water from the reserve tank. During an incubation period of 36-48 $\mathrm{h}$, the overlying water of each core and the reserve tank was sampled $8-10$ times by means of a plastic syringe. The difference between concentration changes in the overlying water of each core and bottom water allowed the calculation of sediment-water fluxes. At the end of the incubation period, each core was subsampled with $2.7 \mathrm{~cm}$ i.d. cores for porewater extraction, porosity profile measurements and granulometric or elemental analysis (see below).

\subsection{Measured flux calculation}

Fluxes were determined by regressing the change in overlying water concentration versus time. Non-significant regressions (Pearson correlation, $P>0.05$ ) based on changes over time that were less than the analytical variability were interpreted as zero fluxes. In spite of the low sampling volume with respect to overlying water volume, the correction for water replacement (with bottom water from the reserve tank) was systematically applied as the consequent error sometimes reached up to $35 \%$ of the flux (Denis, 1999).

\subsection{Analytical procedure for oxygen and nutrient determination}

All flasks were rinsed once before sample collection, and oxygen was immediately analysed by Winkler microtitration (ca. $16 \mathrm{ml}$ ). The remaining sample was filtered through $\mathrm{GF} / \mathrm{F}$ Whatman glass fibre filters. Ammonium was determined at once following the indophenol-blue method of Solorzano (1969). Samples for the analysis of phosphate and silicate were processed in the following few hours using the analytical procedure described in Strickland and Parsons (1972). Nitrate and nitrite samples were deep frozen for later analysis in the laboratory by means of a Technicon Autoanalyzer following the protocol of Tréguer and Le Corre (1975).

Table 1

Location and depth of the stations with the sampling dates, the number of cores studied during Moogli 1 and 2 cruises, and the granulometric composition of surficial sediments. Average porosities in the first centimetre $(0-1 \mathrm{~cm})$ and at depth $(9-10 \mathrm{~cm})$ are also mentioned

\begin{tabular}{|c|c|c|c|c|c|c|c|c|c|}
\hline \multirow{2}{*}{ Station } & \multirow{2}{*}{$\begin{array}{l}\text { Location } \\
{ }^{\circ} \mathrm{N}\end{array}$} & \multirow[b]{2}{*}{${ }^{\circ} \mathrm{E}$} & \multirow{2}{*}{ Depth (m) } & \multicolumn{2}{|c|}{ Sampling date (number of cores) } & \multicolumn{3}{|c|}{ Granulometry } & \multirow{2}{*}{$\begin{array}{l}\text { Porosity } \\
(0-1 \mathrm{~cm} / 9-10 \mathrm{~cm}\end{array}$} \\
\hline & & & & March & June & $\%$ Clay & $\%$ Silt & $\%$ Sand & \\
\hline $\mathrm{C}$ & $43^{\circ} 04.00^{\prime}$ & $05^{\circ} 07.60^{\prime}$ & 162 & $14 / 03(3)$ & $04 / 06(4)$ & 19.5 & 46.1 & 34.3 & $0.579 / 0.413$ \\
\hline $\mathrm{D}$ & $43^{\circ} 14.98^{\prime}$ & $05^{\circ} 08.03^{\prime}$ & 94 & $14 / 03(4)$ & $04 / 06(4)$ & 32.6 & 63.9 & 3.4 & $0.765 / 0.613$ \\
\hline G & $43^{\circ} 03.99^{\prime}$ & $04^{\circ} 44.95^{\prime}$ & 102 & $24 / 03(4)$ & $17 / 06(4)$ & 48.2 & 51.4 & 0.3 & $0.777 / 0.616$ \\
\hline $\mathrm{H}$ & $43^{\circ} 14.53^{\prime}$ & $04^{\circ} 53.10^{\prime}$ & 98 & $24 / 03(3)$ & $24 / 06(3)$ & 37.2 & 61.7 & 1.2 & $0.799 / 0.640$ \\
\hline $\mathrm{K}$ & $42^{\circ} 58.98^{\prime}$ & $04^{\circ} 14.93^{\prime}$ & 98 & $17 / 03(4)$ & $14 / 06(4)$ & 23.2 & 32.5 & 44.2 & $0.602 / 0.492$ \\
\hline $\mathrm{L}$ & $43^{\circ} 11.95^{\prime}$ & $04^{\circ} 12.91^{\prime}$ & 91 & $17 / 03(3)$ & $14 / 06(3)$ & 52.4 & 47.6 & 0.0 & $0.831 / 0.670$ \\
\hline $\mathrm{P}$ & $43^{\circ} 07.28^{\prime}$ & $03^{\circ} 47.93^{\prime}$ & 96 & $20 / 03(4)$ & $14 / 06(4)$ & 41.6 & 53.1 & 5.3 & $0.769 / 0.630$ \\
\hline $\mathrm{S}$ & $42^{\circ} 49.09^{\prime}$ & $03^{\circ} 27.56^{\prime}$ & 99 & $22 / 03(3)$ & $08 / 06(3)$ & 29.8 & 40.5 & 29.7 & $0.741 / 0.559$ \\
\hline $\mathrm{T}$ & $43^{\circ} 00.94^{\prime}$ & $03^{\circ} 19.83^{\prime}$ & 64 & $22 / 03(4)$ & 08/06 (3) & 35.2 & 63.7 & 1.1 & $0.817 / 0.670$ \\
\hline
\end{tabular}




\subsection{Pore-water profiles and predicted flux calculation}

Nutrient profiles (except for silicate concentration not measured) were determined on subcores after rapid slicing with a vertical resolution of $1 \mathrm{~cm}$ down to $10 \mathrm{~cm}$ depth. Interstitial water was extracted by centrifugation (4500 $\mathrm{g}, 20 \mathrm{~min}$ ) and supernatant was carefully removed, diluted with artificial seawater and further analysed following the same standard procedure as for overlying water samples.

Calculations of fluxes were performed according to Fick's first law:

$$
\text { FDiff }=-\Phi \quad D_{\mathrm{s}} \quad(\mathrm{dC} / \mathrm{dz})_{\mathrm{z}=0}
$$

where $\phi$ is the porosity, $D_{\mathrm{S}}$ is the effective diffusion coefficient of the solute in the sediment, $\mathrm{dC} / \mathrm{d} z$ is the estimated concentration gradient just below the sediment-water interface, and $z$ is the depth in the sediment scaled positively downward.

We used Archie's law to estimate tortuosity $\theta\left(\theta^{2}=\phi^{(1-m)}\right)$, with the empirical coefficient $m=3$ (Ullman and Aller, 1982). The effective diffusion coefficient $\left(D_{\mathrm{S}}\right)$ of a solute in the sediment was calculated as described in Denis et al. (2001) from molecular diffusion coefficients given in Boudreau (1997).

To estimate the gradient close to the sediment-water interface $(\mathrm{d} C / \mathrm{d} z)_{z=0}$, different calculations were applied depending on the vertical profile of the solute considered. For ammonium concentrations, a linear gradient over the upper 10 $\mathrm{cm}$ of sediment was considered. For nitrate and nitrite, a peak was always observed in the first centimetre, and the gradient was therefore calculated from the difference between the concentrations in bottom water and in the first slice of sediment $(0-1 \mathrm{~cm})$. Phosphate profiles were fitted by minimum least-square method according to the following empirical formulation (modified from Christensen et al., 1988):

$$
\mathrm{C}_{\mathrm{z}}=\left(\mathrm{C}_{\max }-\mathrm{az}\right)+\left(\mathrm{C}_{0}-\mathrm{C}_{\max }\right) \quad \exp (-\mathrm{bz})
$$

where $C_{0}$ is phosphate concentration in bottom water and $C_{\max }$ is the ordinate at $z=0$ of the linear gradient in phosphate concentration at depth. The coefficient of linear decrease of phosphate concentration at depth was $a$ and the exponential change was $b\left(\mathrm{~cm}^{-1}\right)$. The parameters $C_{\max }, a$ and $b$ were estimated using the standard least-square fitting procedure, and the gradient at the interface $(\mathrm{d} C / \mathrm{d} z)_{z}=0$ was obtained by differentiation with respect to $z$ of Eq. (2):

$$
(\mathrm{dC} / \mathrm{dz})_{\mathrm{z}=0}=-\left(\mathrm{a}+\mathrm{b}\left(\mathrm{C}_{0}-\mathrm{C}_{\max }\right)\right)
$$

\subsection{Sediment characteristics}

Duplicate subcores were sliced every centimetre and deep frozen for the determination of porosity profiles by freezedrying. The total and organic carbon and nitrogen were determined (on the $0-1,2-3$ and 6-7 $\mathrm{cm}$ slices) before and after ignition $\left(550^{\circ} \mathrm{C}-6 \mathrm{~h}\right)$ with a Leco $800 \mathrm{CHN}$ elemental analyser. The granulometric characteristics of the 10 upper centimetres of sediments were determined on June samples by means of a laser granulometer (Laser Malvern Mastersizer).

\subsection{Statistics}

Sediment and bottom water characteristics changes between March and June were tested using the paired $t$-test $(P<$ 0.05) (Scherrer, 1984). For flux measurements, because of the small number of replicates and the variability towards higher values, all data were considered non-normalized and non-parametric tests were applied. Comparisons between cruises were performed with the Wilcoxon-Mann-Whitney test $(P<0.05)$, whereas differences between stations were demonstrated using the Kruskal-Wallis test $(P<0.05)$ and followed by a multiple comparisons test (S.N.K.; $P<0.05$ ) (Scherrer, 1984).

\section{Results}

\subsection{Sediment parameters}

For the stations located on the inner shelf (i.e. Stations D, $\mathrm{H}, \mathrm{L}, \mathrm{P}$ and $\mathrm{T}$ ), the fine fraction (clay + silts) constituted more than $95 \%$ of the sedimentary particles. The silty fraction (47-64\%) generally dominates, except at Station L, where the clay fraction constituted $52 \%$ of the sedimentary particles. Moreover, for those inner shelf stations, porosity profiles showed an exponential decrease with depth, from 0.760.83 in the upper centimetre, down to values in the range 0.61-0.67 at depth Table 1). Similar characteristics were observed for Station G located on the outer shelf but facing the Rhône river mouth. Conversely, sediments from Stations $\mathrm{K}$ and $\mathrm{C}$ had a large component of sand, respectively, 34\% and $44 \%$ of total sediment particles, and a lower porosity (around 0.6 in the upper centimetre down to 0.4 at depth). At Station S, $30 \%$ of the total sediment particles consisted of sand, and the sediment was characterized by a sharp porosity gradient from 0.74 in the first centimetre down to 0.63 in the 2-3 cm slice, and 0.56 at depth.

Vertical variation in organic carbon (OC) and total nitrogen (TN) contents of surficial sediments did not show any general trend. Consequently, the data were pooled, and a mean value was considered for each station and cruise Table 2. The OC ranged from $0.64 \%$ to $1.51 \%$ dry weight, with lower contents at the stations located seawards (C, K and S). Highest OC were measured near the mouth of the Rhône River at Station $\mathrm{H}$, but $\mathrm{OC}$ was also high at Station $\mathrm{L}$ and, to a lower extent, at Station T. The TN was very low in March at all stations Fig. 2, and the spatial trends were in agreement with OC data (significant correlation, $P<0.01$ ), with lowest contents for Stations K and C, and highest contents at Stations $\mathrm{H}$ and L. A significant increase of $\mathrm{OC}$ was observed from March to June. Accordingly, a mean increase in TN content was also observed for all the stations, but the average increase was much more pronounced than for OC $(>50 \%)$. This increase in $\mathrm{TN}$ explained the decrease of the $\mathrm{C} / \mathrm{N}$ atomic 
Table 2

Averaged measurements from triplicates (0-1, 2-3 and 6-7 cm depth) of organic carbon and total nitrogen contents (in percentage of dry weight \pm S.D.) in the Gulf of Lions during the March and June cruises. The OC/TN ratio was calculated from mean values for each station

\begin{tabular}{|c|c|c|c|c|c|c|}
\hline \multirow[t]{2}{*}{ Station } & \multicolumn{3}{|l|}{ March 1998} & \multicolumn{3}{|l|}{ June 1998} \\
\hline & Organic carbon (\% DW) & Total nitrogen (\% DW) & Mean $\mathrm{C} / \mathrm{N}$ ratio & Organic carbon (\% DW) & Total nitrogen (\% DW) & Mean $\mathrm{C} / \mathrm{N}$ ratio \\
\hline$\overline{\mathrm{C}}$ & $0.68 \pm 0.10$ & $0.06 \pm 0.02$ & 9.4 & $0.64 \pm 0.07$ & $0.10 \pm 0.03$ & 6.7 \\
\hline $\mathrm{D}$ & $0.94 \pm 0.14$ & $0.08 \pm 0.03$ & 9.6 & $1.17 \pm 0.08$ & $0.15 \pm 0.05$ & 7.0 \\
\hline $\mathrm{G}$ & $1.02 \pm 0.10$ & $0.08 \pm 0.02$ & 12.3 & $1.00 \pm 0.11$ & $0.11 \pm 0.05$ & 8.4 \\
\hline $\mathrm{H}$ & $1.26 \pm 0.07$ & $0.12 \pm 0.04$ & 9.6 & $1.51 \pm 0.05$ & $0.15 \pm 0.03$ & 9.1 \\
\hline K & $0.64 \pm 0.09$ & $0.04 \pm 0.03$ & 12.9 & $0.71 \pm 0.11$ & $0.07 \pm 0.02$ & 10.2 \\
\hline $\mathrm{L}$ & $1.23 \pm 0.07$ & $0.10 \pm 0.02$ & 10.6 & $1.43 \pm 0.04$ & $0.09 \pm 0.02$ & 14.4 \\
\hline $\mathrm{P}$ & $0.78 \pm 0.05$ & $0.09 \pm 0.03$ & 7.8 & $1.01 \pm 0.13$ & $0.11 \pm 0.03$ & 8.5 \\
\hline $\mathrm{S}$ & $0.72 \pm 0.31$ & $0.06 \pm 0.02$ & 9.5 & $0.75 \pm 0.14$ & $0.11 \pm 0.02$ & 6.1 \\
\hline $\mathrm{T}$ & $1.21 \pm 0.07$ & $0.11 \pm 0.03$ & 9.3 & $1.33 \pm 0.06$ & $0.15 \pm 0.03$ & 7.8 \\
\hline
\end{tabular}

ratio recorded for most stations between March and June. The $\mathrm{C} / \mathrm{N}$ atomic ratios were in the range of 6.1 up to 14.4 , but most of the values were between 7.5 and 10.5. Moreover, a significant positive correlation was observed between OC content and the percentage of fine particles Table 3.

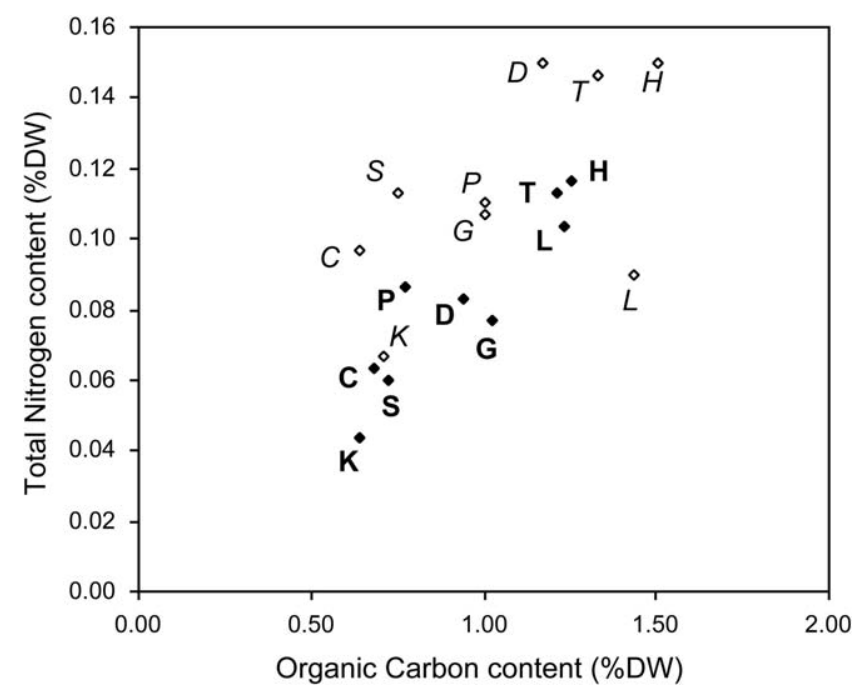

Fig. 2. Relationships between organic carbon and total nitrogen for the March (black diamonds) and June (open diamonds) cruises.

\subsection{Bottom water characteristics}

Bottom waters obtained during the two cruises did not show large variations in most of the measured variables Tables 4 and 5. There was no significant change in salinity between stations and cruises (in the range: 37.95-38.26), but a significant positive correlation with water depth was observed (Table 3). Conversely, an increase in temperature was observed which higher changes at shallower stations. Oxygen concentrations in the bottom water ranged from 208 to $269 \mu \mathrm{M}$ (i.e. $80-103 \%$ saturation) and generally decreased between the two cruises, despite small changes at Stations C and K. Silicate concentrations in bottom water were significantly higher in June, especially at stations in the middle of the continental shelf $(\mathrm{G}, \mathrm{H}, \mathrm{K}, \mathrm{L}, \mathrm{P})$. Moreover, silicate concentrations at outer shelf stations were always higher than those at shallower stations, except for the maximal value recorded in June near the Rhône river mouth (Station $\mathrm{H}$ ). For other nutrients, no significant change was observed in bottom water concentrations between March and June. Ammonium concentrations were always very low, generally in the range 0.07-0.16 $\mu \mathrm{M}$, with maximal values at Station $\mathrm{H}$ for both cruises and no significant correlation with other nutrients. Nitrate concentrations showed a spatial pattern similar to that for silicate, with higher values at outer shelf stations, except for the maximal value recorded in June at Station $H$. Nitrite concentrations were always in the range $0.33-0.73 \mu \mathrm{M}$ with-

Table 4

Bottom water characteristics in the Gulf of Lions during the March and June cruises: temperature, salinity, mean oxygen concentration ( \pm S.D.), percentage of saturation

\begin{tabular}{|c|c|c|c|c|c|c|c|c|}
\hline & March & & & & June & & & \\
\hline Station & $\begin{array}{l}\text { Temperature } \\
\left({ }^{\circ} \mathrm{C}\right)\end{array}$ & Salinity & {$\left[\mathrm{O}_{2}\right](\mu \mathrm{M})$} & $\%$ Sat. & $\begin{array}{l}\text { Temperature } \\
\left({ }^{\circ} \mathrm{C}\right)\end{array}$ & Salinity & {$\left[\mathrm{O}_{2}\right](\mu \mathrm{M})$} & $\%$ Sat. \\
\hline $\mathrm{C}$ & 13.51 & 38.18 & $240 \pm 0.6$ & 92 & 13.40 & 38.26 & $242 \pm 0.2$ & 93 \\
\hline $\mathrm{D}$ & 13.33 & 38.03 & $260 \pm 0.9$ & 100 & 14.22 & 37.96 & $251 \pm 0.2$ & 97 \\
\hline G & 13.29 & 38.03 & $268 \pm 1.2$ & 103 & 13.76 & 38.03 & $228 \pm 0.9$ & 88 \\
\hline $\mathrm{H}$ & 12.91 & 37.98 & $266 \pm 0.9$ & 102 & 14.23 & 37.97 & $234 \pm 1.3$ & 90 \\
\hline K & 13.44 & 38.00 & $252 \pm 1.0$ & 98 & 13.70 & 38.06 & $250 \pm 1.6$ & 95 \\
\hline $\mathrm{L}$ & 12.96 & 37.80 & $266 \pm 1.3$ & 102 & 13.73 & 38.04 & $239 \pm 1.2$ & 92 \\
\hline $\mathrm{P}$ & 13.36 & 38.08 & $254 \pm 1.1$ & 98 & 13.69 & 38.07 & $209 \pm 0.9$ & 80 \\
\hline S & 13.08 & 37.98 & $268 \pm 1.2$ & 103 & 13.47 & 38.06 & $243 \pm 0.5$ & 94 \\
\hline $\mathrm{T}$ & 13.01 & 37.95 & $269 \pm 0.9$ & 103 & 13.90 & 37.96 & $259 \pm 0.9$ & 99 \\
\hline
\end{tabular}


Table 3

Pearson correlation coefficients calculated between depth and the different parameters measured in the sediment (\% clay, \% sand, organic carbon: OC, total nitrogen: TN, C/N atomic ratio: $\mathrm{C} / \mathrm{N}$ ), bottom water temperature (Temp.) and salinity(Sal.), concentrations of different solutes (xx) in bottom water (abbreviated BW xx), total fluxes measured by whole core incubations (Flux xx) and predicted diffusive fluxes calculated from pore-water gradients $\left(F_{\text {Diff }} \mathrm{xx}\right)$ (coefficients significant at $P<0.05$ are in bold)

\begin{tabular}{|c|c|c|c|c|c|c|c|c|c|c|c|c|c|c|c|c|c|c|c|c|c|c|c|c|}
\hline & Depth & $\begin{array}{l}\% \\
\text { Clay }\end{array}$ & $\begin{array}{l}\% \\
\text { Sand }\end{array}$ & $\mathrm{OC}$ & $\mathrm{TN}$ & $\mathrm{C} / \mathrm{N}$ & Temp. & Sal. & $\begin{array}{l}\mathrm{BW} \\
\mathrm{O}_{2}\end{array}$ & $\begin{array}{l}\mathrm{BW} \\
\mathrm{NH}_{4}\end{array}$ & $\begin{array}{l}\mathrm{BW} \\
\mathrm{NO}_{3}\end{array}$ & $\begin{array}{l}\mathrm{BW} \\
\mathrm{NO}_{2}\end{array}$ & $\begin{array}{l}\mathrm{BW} \\
\mathrm{PO}_{4}\end{array}$ & $\begin{array}{l}\mathrm{BW} \\
\mathrm{Si}\end{array}$ & $\begin{array}{l}\text { Flux } \\
\mathrm{O}_{2} \\
\end{array}$ & $\begin{array}{l}\text { Flux } \\
\mathrm{NH}_{4} \\
\end{array}$ & $\begin{array}{l}\text { Flux } \\
\mathrm{NO}_{3} \\
\end{array}$ & $\begin{array}{l}\text { Flux } \\
\mathrm{NO}_{2}\end{array}$ & $\begin{array}{l}\text { Flux } \\
\mathrm{PO}_{4} \\
\end{array}$ & $\begin{array}{l}\text { Flux } \\
\mathrm{Si}\end{array}$ & $\begin{array}{l}F_{\text {Diff }} \\
\mathrm{NH}_{4}\end{array}$ & $\begin{array}{l}F_{\text {Diff }} \\
\mathrm{NO}_{3} \\
\end{array}$ & $\begin{array}{l}F_{\text {Diff }} \\
\mathrm{NO}_{2}\end{array}$ & $\begin{array}{l}F_{\text {Diff }} \\
\mathrm{PO}_{4}\end{array}$ \\
\hline Depth & 1.00 & & & & & & & & & & & & & & & & & & & & & & & \\
\hline$\%$ Clay & -0.49 & 1.00 & & & & & & & & & & & & & & & & & & & & & & \\
\hline$\%$ Sand & 0.52 & -0.81 & 1.00 & & & & & & & & & & & & & & & & & & & & & \\
\hline $\mathrm{OC}$ & -0.55 & 0.65 & -0.81 & 1.00 & & & & & & & & & & & & & & & & & & & & \\
\hline $\mathrm{TN}$ & -0.35 & 0.29 & -0.63 & 0.71 & 1.00 & & & & & & & & & & & & & & & & & & & \\
\hline $\mathrm{C} / \mathrm{N}$ & -0.15 & 0.34 & -0.03 & 0.19 & -0.52 & 1.00 & & & & & & & & & & & & & & & & & & \\
\hline Temp. & -0.02 & -0.05 & -0.07 & 0.27 & 0.48 & -0.19 & 1.00 & & & & & & & & & & & & & & & & & \\
\hline Sal. & 0.76 & -0.53 & 0.49 & -0.59 & -0.29 & -0.24 & 0.12 & 1.00 & & & & & & & & & & & & & & & & \\
\hline $\mathrm{BW} \mathrm{O}$ & -0.31 & -0.01 & -0.07 & 0.03 & -0.16 & 0.19 & -0.60 & -0.45 & 1.00 & & & & & & & & & & & & & & & \\
\hline BW NH & -0.26 & 0.32 & -0.34 & 0.29 & 0.14 & 0.05 & -0.34 & -0.29 & 0.24 & 1.00 & & & & & & & & & & & & & & \\
\hline $\mathrm{BW} \mathrm{NO}$ & 0.47 & -0.06 & 0.22 & -0.17 & -0.14 & 0.01 & 0.36 & 0.48 & -0.85 & -0.11 & 1.00 & & & & & & & & & & & & & \\
\hline $\mathrm{BW} \mathrm{NO}$ & -0.19 & 0.38 & -0.46 & 0.44 & 0.25 & 0.16 & -0.34 & -0.41 & 0.55 & 0.39 & -0.53 & 1.00 & & & & & & & & & & & & \\
\hline $\mathrm{BW} \mathrm{PO}_{4}$ & 0.27 & -0.02 & 0.02 & -0.01 & 0.09 & -0.15 & 0.43 & 0.31 & -0.83 & -0.02 & 0.86 & -0.53 & 1.00 & & & & & & & & & & & \\
\hline BW Si & 0.05 & 0.22 & 0.01 & 0.19 & 0.04 & 0.27 & 0.51 & 0.12 & -0.69 & 0.07 & 0.74 & -0.33 & 0.70 & 1.00 & & & & & & & & & & \\
\hline Flux $\mathrm{O}_{2}$ & -0.15 & 0.44 & -0.49 & 0.66 & 0.41 & 0.16 & 0.29 & -0.11 & -0.37 & 0.33 & 0.32 & 0.11 & 0.42 & 0.46 & 1.00 & & & & & & & & & \\
\hline Flux $\mathrm{NH}_{4}$ & -0.04 & 0.02 & -0.17 & 0.37 & 0.30 & -0.02 & -0.24 & -0.18 & 0.25 & 0.78 & -0.13 & 0.40 & -0.05 & 0.00 & 0.41 & 1.00 & & & & & & & & \\
\hline Flux $\mathrm{NO}_{3}$ & -0.04 & 0.07 & -0.25 & 0.14 & 0.10 & -0.01 & -0.29 & -0.28 & 0.53 & 0.33 & -0.41 & 0.62 & -0.27 & -0.25 & -0.11 & 0.36 & 1.00 & & & & & & & \\
\hline Flux $\mathrm{NO}_{2}$ & 0.28 & -0.17 & 0.28 & -0.18 & 0.11 & -0.26 & 0.36 & 0.46 & -0.66 & 0.00 & 0.62 & -0.64 & 0.49 & 0.52 & 0.02 & 0.04 & -0.57 & 1.00 & & & & & & \\
\hline Flux $\mathrm{PO}_{4}$ & -0.32 & 0.21 & -0.29 & 0.21 & 0.45 & -0.26 & 0.27 & -0.09 & 0.13 & 0.38 & -0.32 & 0.33 & -0.15 & 0.06 & 0.14 & 0.26 & 0.36 & -0.09 & 1.00 & & & & & \\
\hline Flux Si & -0.11 & 0.50 & -0.22 & 0.15 & -0.11 & 0.24 & -0.35 & -0.40 & 0.21 & 0.24 & -0.04 & 0.33 & -0.16 & 0.15 & 0.09 & 0.06 & 0.21 & -0.17 & -0.11 & 1.00 & & & & \\
\hline$F_{\text {Diff }} \mathrm{NH}_{4}$ & -0.44 & 0.43 & -0.69 & 0.74 & 0.64 & -0.09 & 0.06 & -0.42 & 0.00 & 0.71 & -0.02 & 0.45 & 0.18 & 0.13 & 0.66 & 0.67 & 0.26 & -0.09 & 0.32 & 0.10 & 1.00 & & & \\
\hline$F_{\text {Diff }} \mathrm{NO}_{3}$ & 0.11 & 0.15 & -0.06 & -0.10 & -0.11 & 0.14 & 0.10 & 0.00 & 0.10 & -0.27 & -0.19 & 0.20 & -0.15 & 0.05 & -0.23 & -0.36 & 0.43 & -0.38 & 0.34 & 0.00 & -0.39 & 1.00 & & \\
\hline$F_{\text {Diff }} \mathrm{NO}_{2}$ & -0.10 & 0.75 & -0.46 & 0.15 & -0.02 & 0.18 & -0.15 & -0.12 & -0.07 & -0.14 & 0.01 & 0.11 & -0.07 & 0.06 & 0.15 & -0.38 & -0.09 & -0.13 & 0.06 & 0.42 & -0.15 & 0.39 & 1.00 & \\
\hline$F_{\text {Diff }} \mathrm{PO}_{4}$ & -0.44 & 0.16 & -0.44 & 0.55 & 0.56 & -0.20 & 0.08 & -0.42 & 0.09 & 0.67 & -0.13 & 0.46 & 0.08 & 0.02 & 0.51 & 0.64 & 0.30 & -0.22 & 0.40 & -0.02 & 0.90 & -0.34 & -0.39 & 1.00 \\
\hline
\end{tabular}


Table 5

Bottom water characteristics in the Gulf of Lions during the March and June cruises: averaged nutrient concentrations in $\mu \mathrm{M}$ ( \pm S.D.)

\begin{tabular}{|c|c|c|c|c|c|c|c|c|c|c|}
\hline Stations & $\begin{array}{l}\text { March } \\
{\left[\mathrm{NH}_{4}^{+}\right]}\end{array}$ & {$\left[\mathrm{NO}_{3}{ }^{-}\right]$} & {$\left[\mathrm{NO}_{2}{ }^{-}\right]$} & {$\left[\mathrm{PO}_{4}{ }^{3-}\right]$} & {$\left[\mathrm{Si}(\mathrm{OH})_{4}\right]$} & $\begin{array}{l}\text { June } \\
{\left[\mathrm{NH}_{4}^{+}\right]}\end{array}$ & {$\left[\mathrm{NO}_{3}{ }^{-}\right]$} & {$\left[\mathrm{NO}_{2}{ }^{-}\right]$} & {$\left[\mathrm{PO}_{4}{ }^{3-}\right]$} & {$\left[\mathrm{Si}(\mathrm{OH})_{4}\right]$} \\
\hline $\mathrm{C}$ & $0.07 \pm 0.03$ & $4.1 \pm 0.3$ & $0.33 \pm 0.01$ & $0.11 \pm 0.01$ & $2.4 \pm 0.2$ & $0.07 \pm 0.01$ & $2.6 \pm 0.3$ & $0.53 \pm 0.02$ & $0.03 \pm 0.01$ & $1.9 \pm 0.3$ \\
\hline D & $0.14 \pm 0.03$ & $0.9 \pm 0.1$ & $0.58 \pm 0.03$ & $0.03 \pm 0.02$ & $0.7 \pm 0.2$ & $0.08 \pm 0.00$ & $0.6 \pm 0.3$ & $0.61 \pm 0.02$ & $0.01 \pm 0.01$ & $1.6 \pm 0.3$ \\
\hline $\mathrm{G}$ & $0.09 \pm 0.03$ & $1.2 \pm 0.2$ & $0.71 \pm 0.02$ & $0.01 \pm 0.03$ & $2.3 \pm 0.5$ & $0.12 \pm 0.05$ & $3.1 \pm 0.3$ & $0.38 \pm 0.01$ & $0.10 \pm 0.01$ & $5.3 \pm 1.1$ \\
\hline $\mathrm{H}$ & $0.31 \pm 0.03$ & $0.7 \pm 0.1$ & $0.73 \pm 0.02$ & $0.03 \pm 0.06$ & $2.0 \pm 0.5$ & $0.17 \pm 0.04$ & $4.3 \pm 0.1$ & $0.59 \pm 0.02$ & $0.13 \pm 0.02$ & $6.4 \pm 0.6$ \\
\hline $\mathrm{K}$ & $0.10 \pm 0.03$ & $2.5 \pm 0.1$ & $0.42 \pm 0.03$ & $0.03 \pm 0.06$ & $3.1 \pm 0.7$ & $0.13 \pm 0.02$ & $2.4 \pm 0.2$ & $0.36 \pm 0.01$ & $0.07 \pm 0.01$ & $5.3 \pm 1.4$ \\
\hline $\mathrm{L}$ & $0.16 \pm 0.08$ & $1.3 \pm 0.2$ & $0.64 \pm 0.02$ & $0.01 \pm 0.02$ & $1.7 \pm 0.6$ & $0.14 \pm 0.02$ & $2.7 \pm 0.1$ & $0.56 \pm 0.03$ & $0.02 \pm 0.00$ & $4.9 \pm 1.8$ \\
\hline $\mathrm{P}$ & $0.24 \pm 0.08$ & $2.8 \pm 0.2$ & $0.46 \pm 0.01$ & $0.05 \pm 0.01$ & $2.6 \pm 0.4$ & $0.11 \pm 0.03$ & $4.7 \pm 0.2$ & $0.39 \pm 0.01$ & $0.18 \pm 0.02$ & $4.9 \pm 0.3$ \\
\hline S & $0.13 \pm 0.05$ & $1.0 \pm 0.2$ & $0.57 \pm 0.02$ & $0.01 \pm 0.04$ & $1.5 \pm 0.5$ & $0.12 \pm 0.04$ & $2.2 \pm 0.2$ & $0.53 \pm 0.01$ & $0.02 \pm 0.00$ & $1.7 \pm 0.3$ \\
\hline $\mathrm{T}$ & $0.11 \pm 0.03$ & $0.9 \pm 0.1$ & $0.54 \pm 0.01$ & $<0.01$ & $1.4 \pm 0.3$ & $0.10 \pm 0.02$ & $0.2 \pm 0.1$ & $0.41 \pm 0.01$ & $0.02 \pm 0.01$ & $0.9 \pm 0.3$ \\
\hline
\end{tabular}

out general pattern and maximal values were observed near the Rhône river mouth for both cruises. In March, phosphate concentrations were always close to the detection limit, generally lower than $0.03 \mu \mathrm{M}$ except for Station C, and very low concentrations were also recorded in June (except Stations P, $\mathrm{G}$ and $\mathrm{H})$. There was a general positive significant relationship between nitrate, phosphate and silicate concentrations in
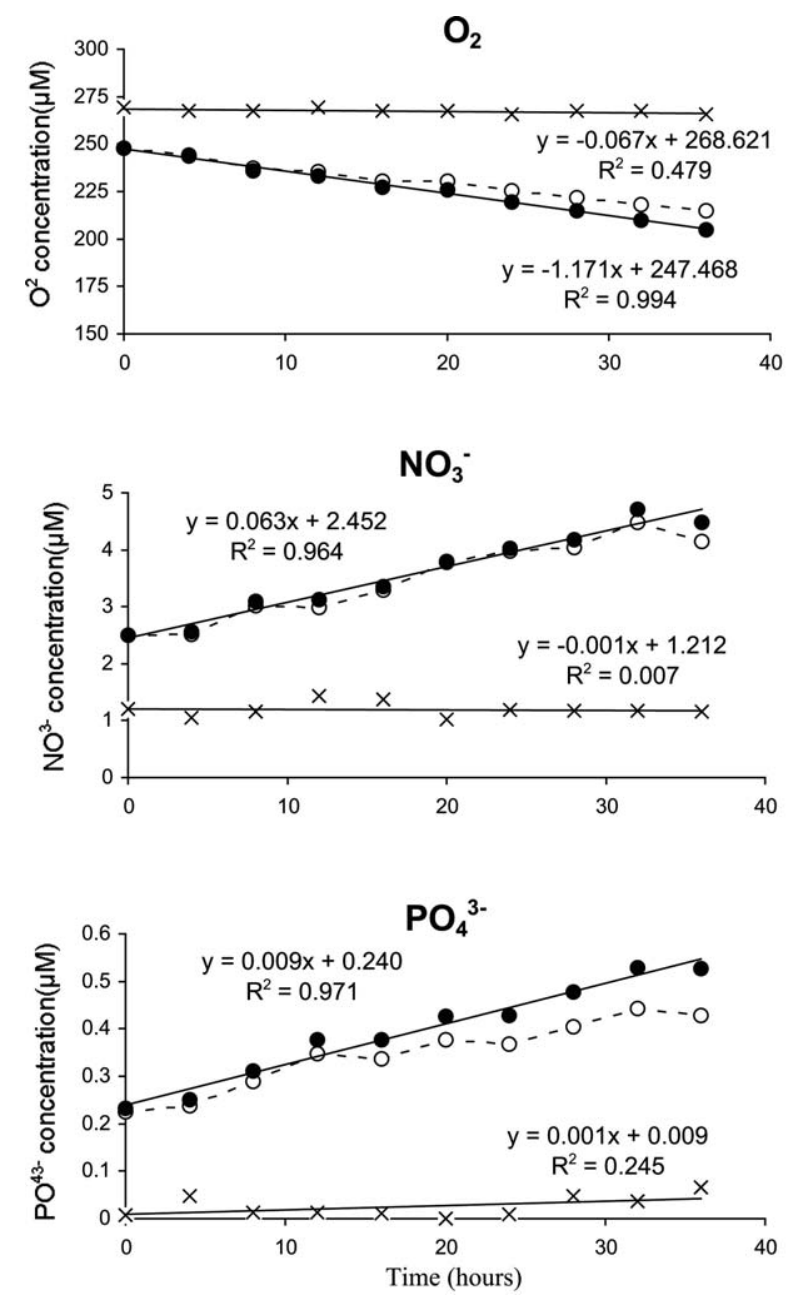

bottom water, and negative correlations of these nutrients with nitrite and oxygen concentrations Table 3.

\subsection{Sediment-water fluxes}

Fig. 3 illustrates times series of oxygen and nutrients in the overlying water of a core (March 1998, Station G, core
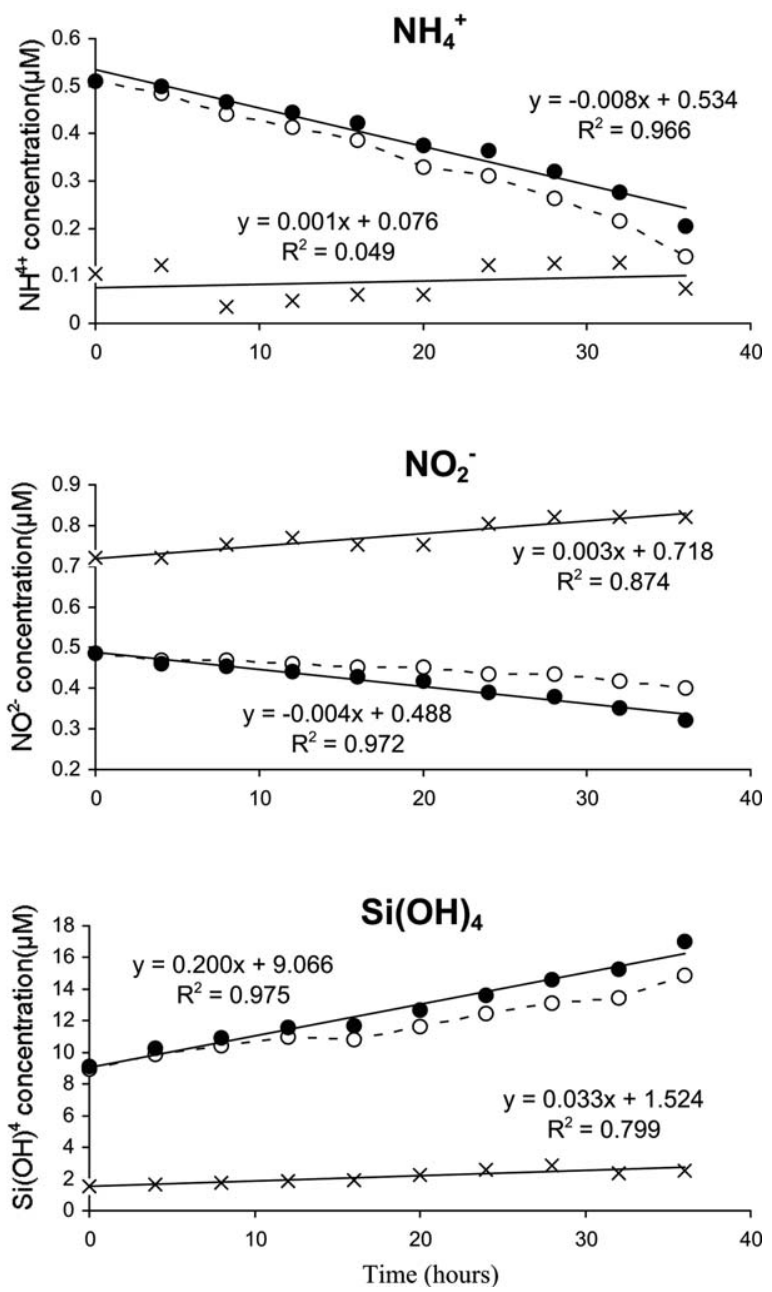

Fig. 3. Example of oxygen and nutrient changes in the overlying water of a core (March cruise, Station G, core no. 2) and in the bottom water (open circles) that forms the basis of the benthic flux estimates during an incubation experiment. For the overlying water of the core, raw data (cross) are shown as well as corrected data (black circles) used for flux calculations. Regressions for corrected data and bottom water are also shown. 

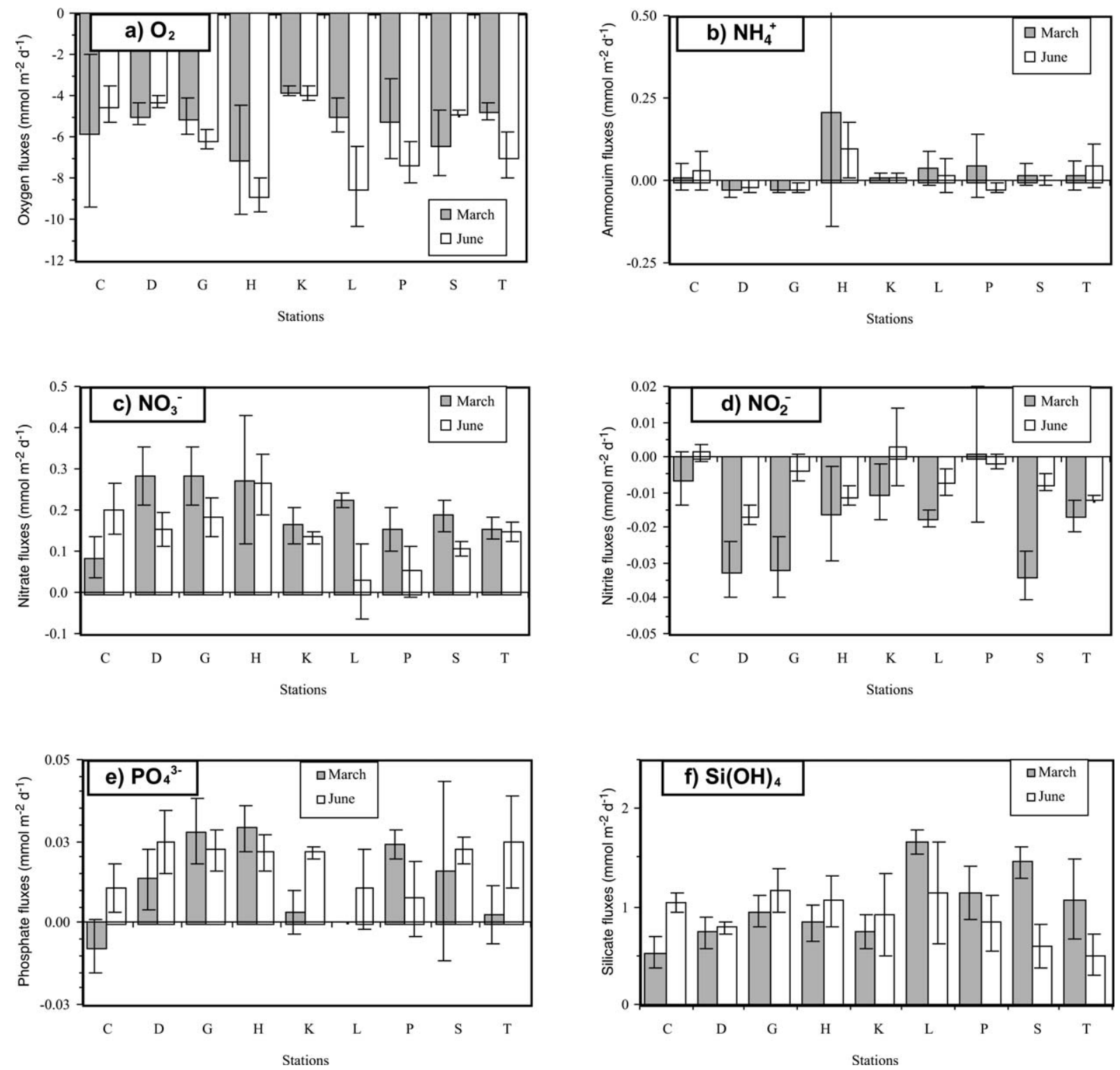

Fig. 4. Average ( \pm S.D.) sediment oxygen demand (a), ammonium (b), nitrate (c), nitrite (d), phosphate (e) and dissolved silica fluxes (f) measured by whole core incubation at the stations visited during the March and June cruises in the Gulf of Lions.

no. 2) and in the reserve tank. As expected, fluxes in the reserve tank were always low and generally non-significant, and the correction for bottom water replacement of overlying water was applied before flux calculations.

\subsubsection{Oxygen}

Shipboard incubation measurements of oxygen fluxes for both cruises are presented in Fig. 4a All the incubations resulted in significant fluxes $(P<0.05)$, and individual fluxes varied over similar ranges in March and June, from -3.14 to -11.16 and from -3.53 to $-10.87 \mathrm{mmol} \mathrm{m}^{-2} \mathrm{~d}^{-1}$, respectively. No significant correlation was observed between oxygen fluxes and depth. The smallest fluxes (averaging $-3.82 \mathrm{mmol}$ $\mathrm{m}^{-2} \mathrm{~d}^{-1}$ on both cruises) were recorded at Station $\mathrm{K}$, with low variability between cores and cruises. The maximal flux was recorded at Station $\mathrm{H}$ for both cruises, with values close to those at Station L in June. Station D showed low oxygen fluxes when compared with other inner shelf stations located west of the Rhône river mouth.

Significant differences existed between stations in June, but not in March. The high variability observed at Stations C and $\mathrm{H}$ in March was basically due to a single core with a measured oxygen flux around $-11 \mathrm{mmol} \mathrm{m}^{-2} \mathrm{~d}^{-1}$ in both cases, whereas values for the three other cores averaged -3.89 and $-5.78 \mathrm{mmol} \mathrm{m}^{-2} \mathrm{~d}^{-1}$, respectively. For June, only extreme averages at Stations $\mathrm{K}$ and $\mathrm{H}$ were significantly different from each other. Considering the transects parallel to the coast, median values were generally higher for inner shelf stations than for stations located near the continental shelf break ( $\mathrm{D}>\mathrm{C} ; \mathrm{H}>\mathrm{G}$; L > K; T > S). Oxygen flux was higher in June for Stations $\mathrm{L}$ and $\mathrm{T}$, whereas a significant decrease occurred at Station S. No significant difference was 
observed for the other stations, but oxygen fluxes showed a significant relationship with OC content in surficial sediments Table 3.

\subsubsection{Ammonium}

Ammonium exchanges were generally very low Fig. 4b, and about one-third of the individual fluxes were not significant. Moreover, the standard deviations obtained for each station were always of the same order of magnitude as fluxes. Averaged fluxes were in the range -0.034 to $+0.101 \mathrm{mmol}$ $\mathrm{m}^{-2} \mathrm{~d}^{-1}$, obtained, respectively, for Stations D and H. No significant change was observed either between the cruises or between the stations, but highest fluxes were always measured at Station $\mathrm{H}$. The relationship between ammonium and oxygen fluxes Table 3 resulted from only a few cores with 'abnormally high' oxygen flux and very high ammonium release, certainly due to enhanced macrofaunal activity. Ammonium fluxes were positively correlated with bottom water ammonium concentrations $(r=0.78)$.

\subsubsection{Nitrate}

Nitrate fluxes were generally directed from the sediment to the overlying water, at rates up to $0.475 \mathrm{mmol} \mathrm{m}^{-2} \mathrm{~d}^{-1}$. The incubation of only three of 67 cores resulted in nonsignificant fluxes. A significant difference was observed between stations in March and June, but only extreme values were significantly different $(\mathrm{C} \neq \mathrm{D} ; \mathrm{C} \neq \mathrm{G}$ in March; $\mathrm{L} \neq \mathrm{H}$ in June, $P<0.05)$. In March, Stations D, G and $\mathrm{H}$ showed relatively high nitrate release $\left(>0.240 \mathrm{mmol} \mathrm{m}^{-2} \mathrm{~d}^{-1}\right)$, whereas the release was minimal at Station C. On the western part of the continental shelf, fluxes varied in a lower range, between 0.139 and $0.166 \mathrm{mmol} \mathrm{m} \mathrm{m}^{-2} \mathrm{~d}^{-1}$. Nitrate fluxes in June were generally lower than in March, but this decrease was only significant for Stations D, L and S. The only exception to this general trend was Station C, where nitrate release doubled during the same period. There was a negative correlation between nitrate flux and nitrite flux, whereas a positive relationship was calculated with nitrite concentrations in bottom water.

\subsubsection{Nitrite}

Nitrite fluxes were always low, in the range of -0.043 to $0.026 \mathrm{mmol} \mathrm{m}^{-2} \mathrm{~d}^{-1}$ for the March cruise and in the range of -0.022 to $0.019 \mathrm{mmol} \mathrm{m}^{-2} \mathrm{~d}^{-1}$ in June. Most fluxes were directed towards the sediments, except four significant positive fluxes. A significant difference between stations was observed in June, basically due to Station D, where high fluxes were directed into the sediment. Nitrite uptake by the sediment was lower in June, with significant changes at Stations D, G, L, S and T. Moreover, a significant negative correlation was noticed between nitrite fluxes and bottom water nitrite concentrations $(r=-0.64$, Table 3 .

\subsubsection{Phosphate}

Phosphate fluxes were also quite low, generally directed towards the water column in the range $0-0.036 \mathrm{mmol} \mathrm{m}^{-2}$ $\mathrm{d}^{-1}$, except three negative fluxes in March $(-0.016$ and -0.013 at Station C; -0.005 at Station T). Around one-fourth of the fluxes were not significant $(P<0.05)$, with no significant flux in March at Station L. A significant difference between stations was observed in March, but only extreme averaged fluxes (Station $\mathrm{C}$ and $\mathrm{H}$ ) were significantly different. No general difference was recorded between cruises except at Station C, with a phosphate uptake in March and a release in June. There was also a significant increase of phosphate release at Station K.

\subsubsection{Silicate}

Silicate fluxes were always significant $(P<0.05)$ and directed towards the water column in the range $0.29-1.80$ mmol m $\mathrm{m}^{-2} \mathrm{~d}^{-1}$. There were differences between stations in March, but not in June, and multiple comparison tests showed again that only extreme values were significantly different (Stations C and L). Silicate release in March was higher for western stations (Stations L, P, S and T), and maximal values were observed at Station $\mathrm{L}$ for both cruises. As a general change between March and June, an increase in silicate release was observed for stations located on the eastern part of the continental shelf, whereas there was a decrease for western stations. Nevertheless, the only significant changes in time were at Stations C and S.

\subsubsection{Pore-water profiles and predicted fluxes}

Porewater profiles were generally similar for both cruises, and when changes were recorded, these were attributed to spatial heterogeneity, because no significant trend was observed. Consequently, pore-water data were averaged over both cruises (Fig. 5), but predicted fluxes were calculated individually, and averaged values $( \pm$ S.D.) are presented in Fig. 6 . For all the stations sampled, ammonium concentrations showed a significant increase with depth in the sediment and, generally, the profiles were linear $(r=0.93$, $P<0.001)$. Concentrations varied in the range $70-175 \mu \mathrm{M}$ for the $9-10 \mathrm{~cm}$ depth slice. The vertical gradient was stronger for Station $\mathrm{H}$, where maximal ammonium concentrations were measured at depth. As a consequence, predicted fluxes of ammonium also showed great variability Fig. 6a, with highest predicted fluxes at Station $\mathrm{H}$ and minimal values around $0.024 \mathrm{mmol} \mathrm{m}^{-2} \mathrm{~d}^{-1}$ for Stations $\mathrm{C}$ and $\mathrm{K}$. There was a significant positive correlation between predicted fluxes of ammonium and the organic contents of surficial sediments as well as bottom water ammonium concentrations and fluxes of oxygen and ammonium as measured by whole core incubations Table 3. Ammonium predicted fluxes hence followed the general trend observed for measured fluxes, particularly with highest release at Station $\mathrm{H}$.

Nitrate concentrations in the interstitial water varied from undetectable values at depth to maximal values near the sediment-water interface. For all the stations analysed, the nitrate peak was located in the first centimetre of the sediment with concentrations in the range of 5.6-17 $\mu \mathrm{M}$. A 


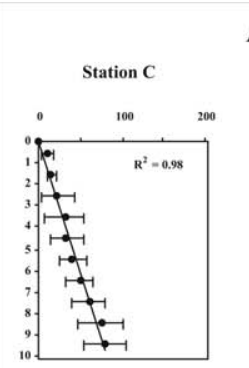

Ammonium : $\mathrm{NH}_{4}^{+}$

Station D

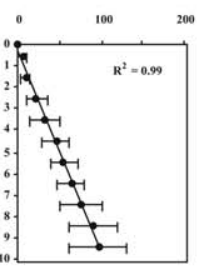

Station H

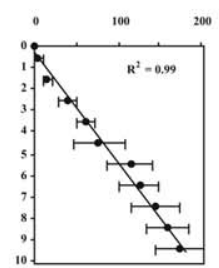

Station P
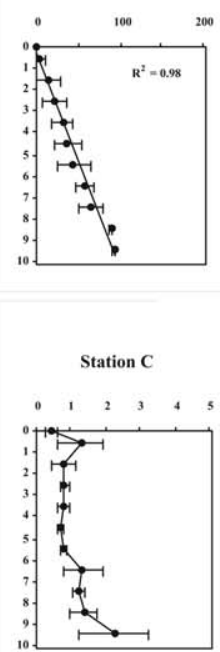

Station $\mathbf{H}$

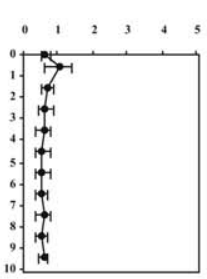

Station $\mathbf{P}$

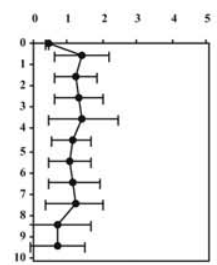

Station K

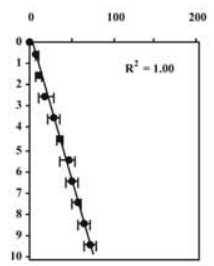

Station S

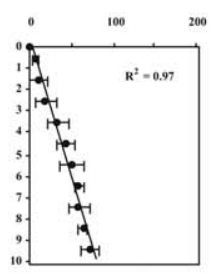

Nitrite : $\mathrm{NO}_{2}$

Station D

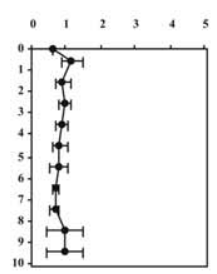

Station K

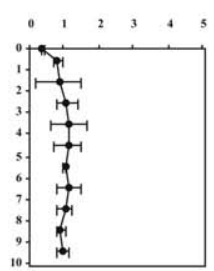

Station S

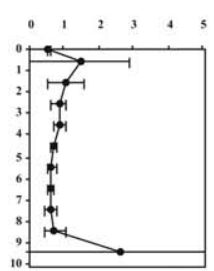

Nitrate : $\mathrm{NO}_{3}$

Station D
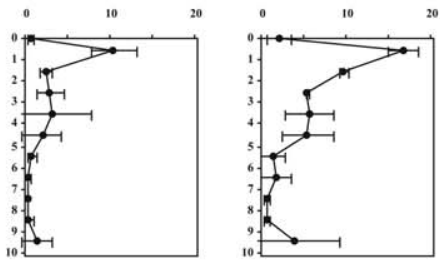

Station H
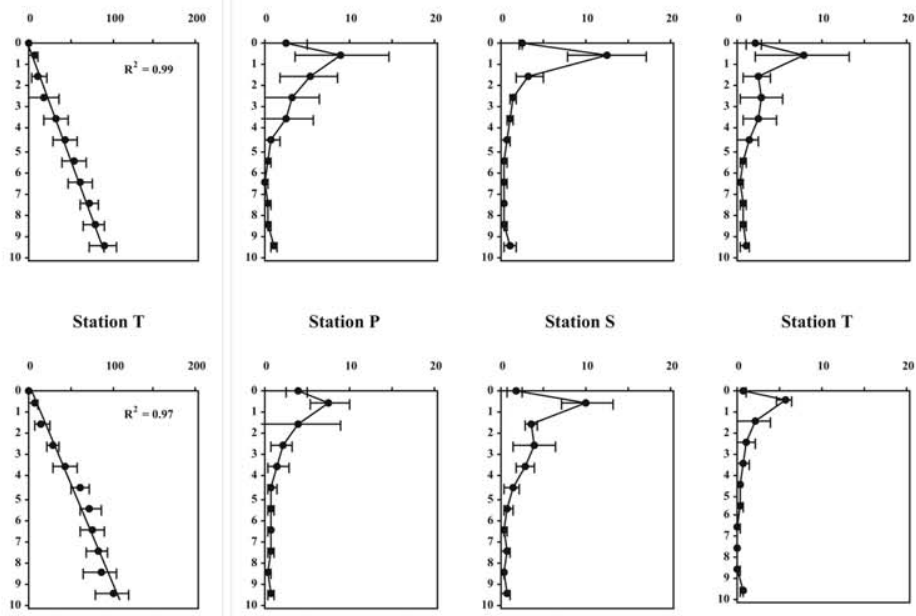

Phosphate : $\mathrm{PO}_{4}{ }^{3}$

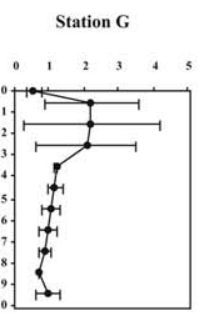

Station C
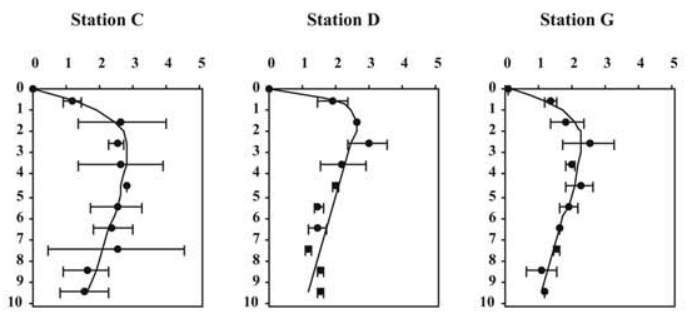

Station L

Station $\mathbf{H}$
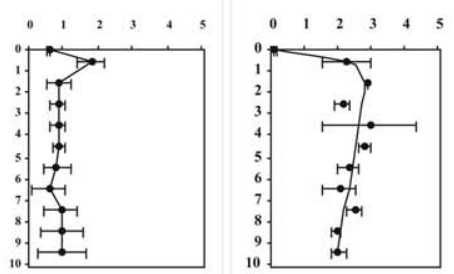

Station K

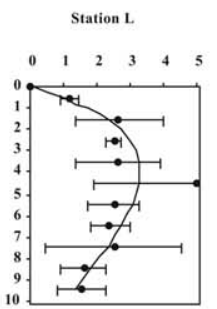

Station $\mathrm{T}$
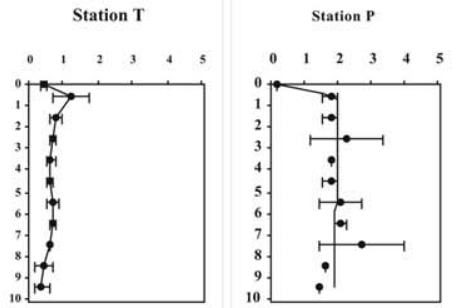

Station T

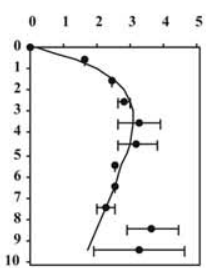

Fig. 5. Variation with depth $(0-10 \mathrm{~cm})$ in the sediment of ammonium, nitrate, nitrite and phosphate concentrations in the interstitial waters of sediments from the Gulf of Lions. Values given are averages of March and June cruises, and data at the sediment-water interface (depth zero) are derived from Tables 4 and 5. 

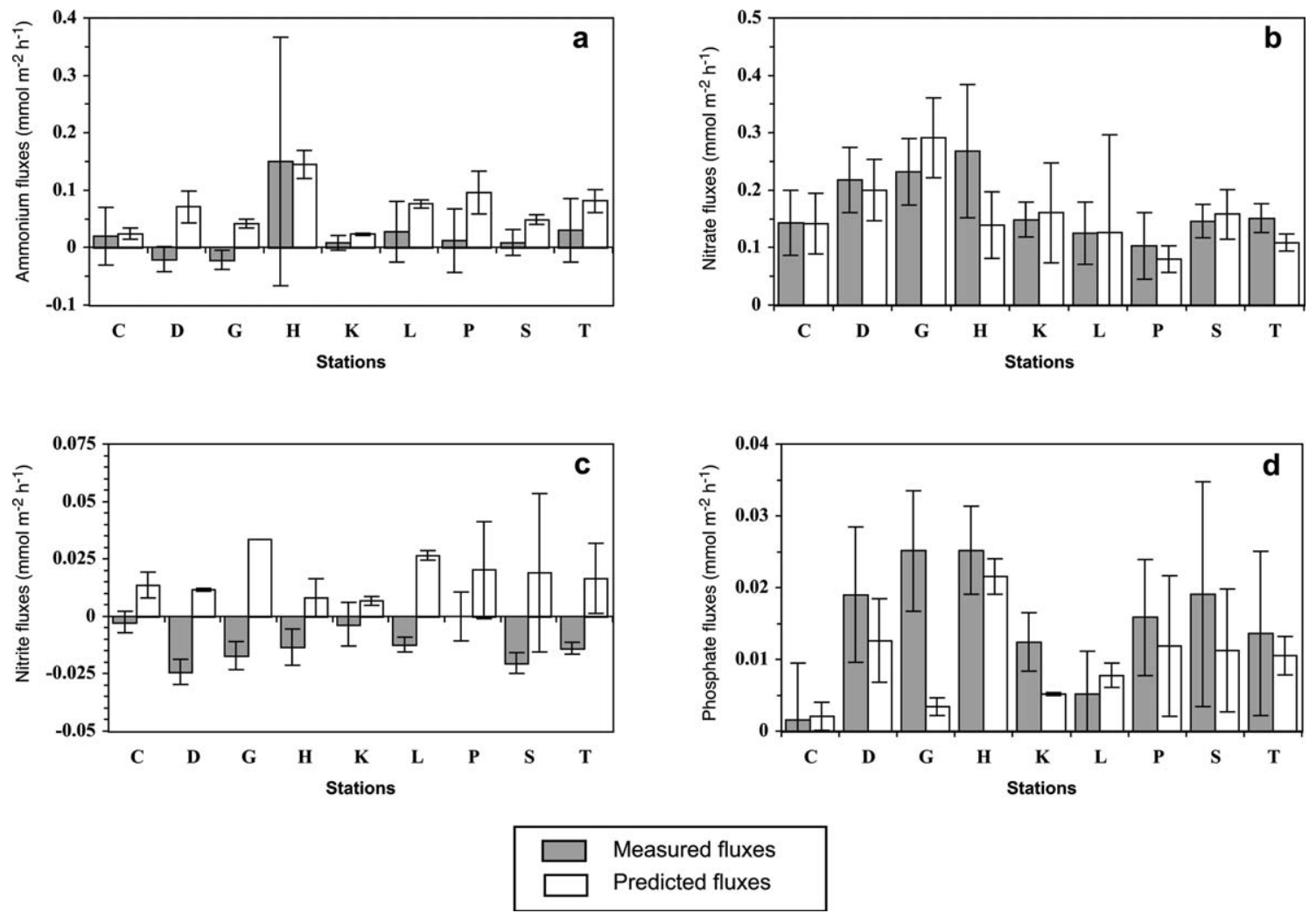

Fig. 6. Mean measured fluxes (in grey) for each station and mean predicted fluxes (in white) as calculated from interstitial water profiles of ammonium (a), nitrate (b), nitrite (c) and phosphate (d). Averaged predicted fluxes ( \pm S.D.) of four replicates (two in March, two in June) are given. Details of calculations are given in the text and averaged profiles are given in Fig. 5.

similar trend was generally observed for nitrite concentrations even where the vertical gradient was very weak. Nitrite concentrations were always low, generally lower than $2 \mu \mathrm{M}$, with a higher variability. These profiles resulted in predicted nitrate and nitrite fluxes directed from the sediment towards the overlying water. Averaged predicted fluxes of nitrate varied in the range $0.079-0.290 \mathrm{mmol} \mathrm{m} \mathrm{m}^{-2} \mathrm{~d}^{-1}$, whereas maximal predicted fluxes of nitrite reached a value close to $0.036 \mathrm{mmol} \mathrm{m}^{-2} \mathrm{~d}^{-1}$. Maximal predicted fluxes of nitrate and nitrite were recorded at Station G and more generally in the eastern part of the area studied (D, G and H). Lowest nitrate fluxes were calculated at Station P. For predicted nitrite fluxes, western stations generally had higher fluxes, but also associated with a large variability. In spite of the good agreement between measured and predicted fluxes of nitrate while averaging all data for each station Fig. 6b, no significant correlation was observed when considering individual data Table 3. Predicted nitrite fluxes remain low but always positive, whereas measured fluxes were directed towards the sediments, which may be partly explained by the low concentrations observed in the interstitial water and the weak gradient.

Phosphate profiles were highly variable, especially at Stations $\mathrm{L}$ and $\mathrm{C}$, but a general downcore trend was observed with very low concentrations in bottom water (always below $0.15 \mu \mathrm{M}$ ), an increase with depth in the first centimetres (up to concentrations around $3-4 \mu \mathrm{M}$ at $1-4 \mathrm{~cm}$ depth), and a decrease at depth, which was less marked for Station P. The formulation previously described fitted the data relatively well. Averaged predicted fluxes of phosphate varied over a large range, from $0.004 \mathrm{mmol} \mathrm{m}^{-2} \mathrm{~d}^{-1}$ at Station $\mathrm{C}, \mathrm{G}$ and $\mathrm{K}$, up to $0.019 \mathrm{mmol} \mathrm{m}^{-2} \mathrm{~d}^{-1}$ at Station H. Despite the low concentrations, predicted fluxes agreed relatively well with measured fluxes, except for the large discrepancy at Station G. Predicted phosphate fluxes were positively correlated with ammonium concentrations in bottom water and measured and predicted ammonium fluxes Table 3 .

\section{Discussion}

\subsection{Sediment parameters}

Sediment characteristics varied with bathymetry Table 3, but also with the topography: surficial sediments of Stations C, K and $\mathrm{S}$ near the continental shelf break showed a large sandy fraction and low porosity and might be considered as a mixture between outer shelf and upper slope sediments. Sediments from all other stations were largely dominated by the silt + clay fraction and can be characterized as prodeltaic or deltaic environments as described by Chassefiere (1990). Sediment composition appears to be mainly the result of particulate input from the Rhone river, which is equivalent to $80 \%$ of the fine particle input to the Gulf of Lions (Leveau and Coste, 1987): higher porosities were ob- 
served for stations close to the delta (i.e. Stations G, H and L) and certainly submitted to largest inputs from the Rhône river. However, we must notice that our analysis does not take into account the vertical stratification that may result from resuspension and deposition events.

The OC and TN contents are in the range of earlier measurements in the same area (Blackburn, 1991; Buscail and Germain, 1997) and follow a distribution close to the one observed for fine particles. The amount of OC and TN clearly decrease from the mouth of the Rhone River towards west and south, hence evidencing the major role of fluvial inputs (organic compounds and/or nutrients supporting primary production) and their dispersion via the North Mediterranean Current on mineralization processes in surficial sediments. Increases of $\mathrm{OC}$ and $\mathrm{TN}$ contents were recorded between March and June for all stations, respectively, averaging 12\% and $43 \%$, but only TN increase was significant. This might be considered as the result of the sedimentation of a spring phytoplankton bloom that occurred in late March-early April, as recorded on a sediment trap located $20 \mathrm{~m}$ above the bottom at Station C (Denis et al., 2001). The impact of such a vertical input of fresh organic matter has been described earlier, mostly in shallower waters, where the sedimentwater column coupling is tighter than in deeper environments. We suggest that the input of fresh OC due to postbloom sedimentation was too low to obtain a significant change in OC content of surficial sediments, whereas $\mathrm{C} / \mathrm{N}$ ratio shows significant variations, which has earlier been pointed out during a temporal study in the North Adriatic Sea (Bertuzzi et al., 1996).

\subsection{Sedimentary biogeochemical processes}

\subsubsection{Oxygen}

Our exchanges of oxygen at the sediment-water interface are in accordance with previous data collected in the frame of the Eros 2000 project. Globally, the variability recorded $\left(-0.19\right.$ to $\left.-25.82 \mathrm{mmol} \mathrm{m}^{-2} \mathrm{~d}^{-1}\right)$ was higher than the ones that we observed. This is basically due to a sampling strategy focussed around the mouth of the Rhone River at shallower stations but also considering the bathymetric gradient down to deep-sea sediments, along five cruises from July 1987 to December 1991. Our study focussed on the continental shelf with depth ranging from 60 to $160 \mathrm{~m}$, with a regular sampling in a short time period. This results in a lower variability, as all individual oxygen flux measurements were in the range from -3.14 to $-11.16 \mathrm{mmol} \mathrm{m}^{-2} \mathrm{~d}^{-1}$. A weak gradient was observed, with highest fluxes near the Rhône river mouth (Station $\mathrm{H}$, and to a smaller extent $\mathrm{L}, \mathrm{P}$ and $\mathrm{G}$ ) and lower sediment oxygen demand near the continental shelf break (Stations K and C) and on the eastern part of the area (Station D). Considering the averaged values for each station, there was barely a factor of two between the lowest and highest oxygen fluxes, and the increase was significantly correlated with the OC content of surficial sediments $(r=0.66)$. This spatial homogeneity is remarkable for a continental shelf subjected to massive freshwater and organic matter input from the Rhône River. No clear sediment record of the dilution plume of the Rhône river was observed on the continental shelf, which is surprising, considering that Zuo et al. (1993) found that $40 \%$ of the material supplied by the Rhône river was deposited on the continental shelf. In the case of the continental shelf in the Gulf of Lions, this must be basically due to hydrodynamic features, and especially to wind effects that are responsible for (1) the direction of the plume dilution that may vary widely (Pinazo et al., 2001), and (2) the occurrence of resuspension-deposition events on the continental shelf and subsequent lateral transport by the alongslope circulation as previously shown by Durrieu de Madron et al. (1999). This leads to a wide dilution of the large amount of organic matter brought by the Rhône River, and indirectly produced after the input of nutrients. Moreover, a large part of the organic matter might just be transferred through the continental shelf via structures such as the nepheloid benthic layer and the numerous submarine canyons that incise the outer part of the continental shelf as well as the continent slope (Got and Aloisi, 1990). This would suggest a relatively high sediment oxygen demand near the bottom of the slope in the axis of the canyons, as earlier pointed out by Tahey et al. (1994).

\subsubsection{Nitrogen}

The variability in ammonium exchanges as well as numerous non-significant fluxes reduce the strength of the conclusions we can derive from our results. Interstitial profiles of ammonium were consistent with literature data, with a linear increase in ammonium concentration with depth, related to the organic matter consumption, but concentrations observed in the first centimetres result in the balance between ammonification and nitrification as well as possible ammonium uptake by benthic algae. As previously stated on individual cores, high ammonium releases were generally observed during whole core incubations simultaneous with high oxygen uptake rates, and might therefore evidence the presence of large macrofaunal organisms that we occasionally identified (Denis, 1999). But while considering the whole data set, predicted fluxes were always positive and generally higher than measured fluxes, hence demonstrating that irrigation fluxes were very low except within a few cores, but also suggesting that ammonium was actively nitrified within the first millimetres of the sediment. Moreover, significant ammonium fluxes directed from the water column to the sediment were recorded at Stations D and G, where interstitial profiles did not provide evidence of enhanced ammonium accumulation, suggesting a high nitrification rate. Conversely, nitrate release as measured by whole core incubation and calculated from pore-water profiles was quite high for all the stations. All interstitial profiles of nitrate were characterized by a subsurface maximum, suggesting that nitrification was the main nitrate source for denitrification, rather than nitrate diffusing from the overlying water (Lohse et al., 1996). Further calculations using average flux measurements 


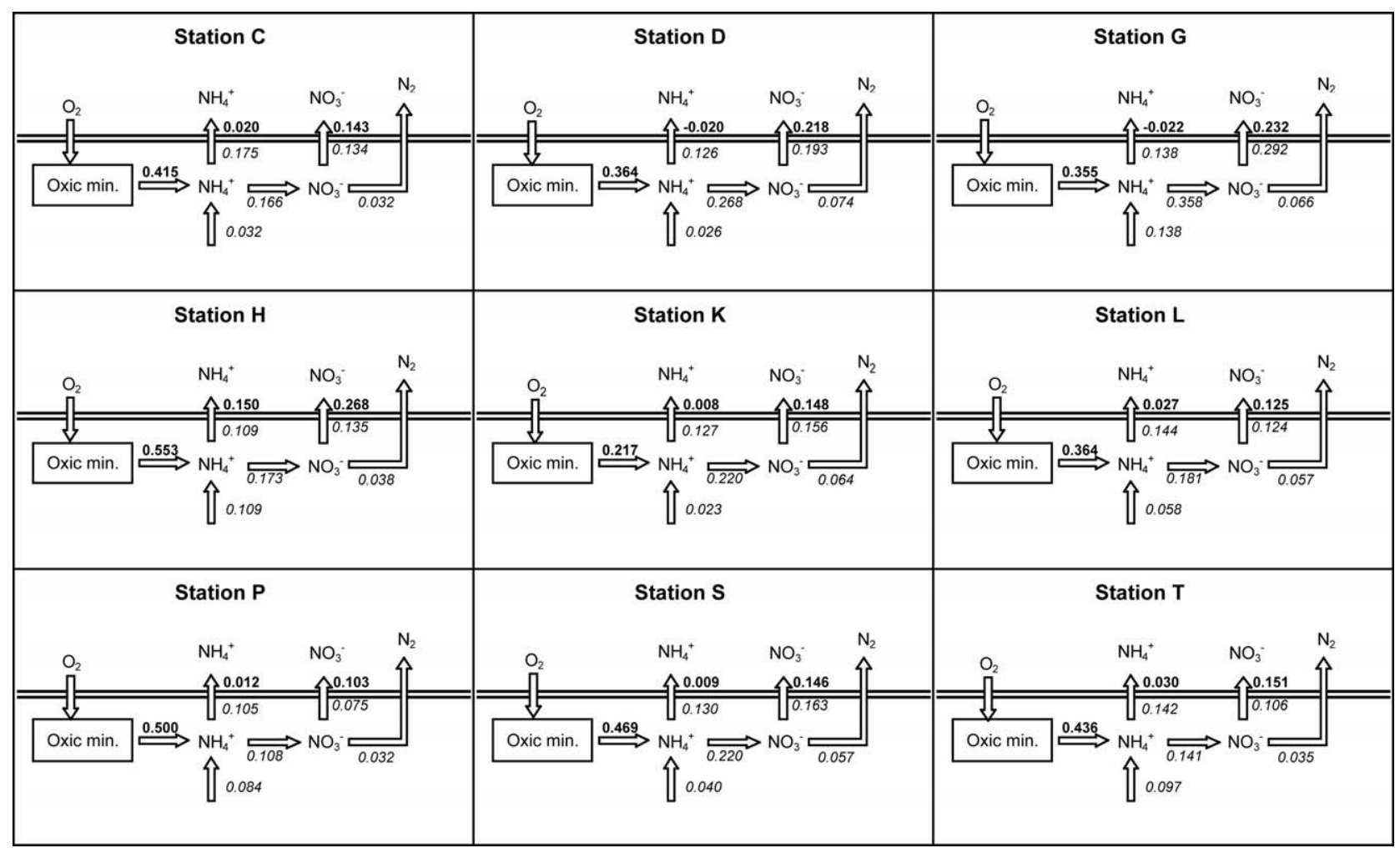

Fig. 7. Proposed inorganic nitrogen budget in surficial sediments for each station studied on the continental shelf in the Gulf of Lions. Nitrification and denitrification rates are minimal values and were estimated from nitrate profiles (see text for details). Predicted (italics) and averaged (bold) measured fluxes of nitrate and ammonium at the sediment-water interface are mentioned. Input of ammonium from oxic mineralization was calculated from sediment oxygen demand using the averaged $\mathrm{C} / \mathrm{N}$ ratio reported in Table 2.

and interstitial profiles at each station were performed to establish nitrogen mass balances in surficial sediments. Since the measured and predicted nitrate fluxes were in close agreement, molecular diffusion appeared to be the major mode of transport. We calculated the minimum estimate of depth integrated nitrification from nitrate profiles, by summing the maximum upward and maximum downward fluxes of nitrate. Calculated nitrification rates ranged from 0.10 to $0.37 \mathrm{mmol}$ $\mathrm{m}^{-2} \mathrm{~d}^{-1}$, with maximal values at Station $\mathrm{G}$ Fig. 7). Minimal denitrification rate was calculated from the maximum downward predicted flux of nitrate and ranged from 0.032 to 0.074 mmol m $\mathrm{m}^{-2} \mathrm{~d}^{-1}$. We also considered predicted and measured fluxes at the sediment-water interface in the functional scheme of the first centimetre of sediment, as well as predicted fluxes of ammonium from deeper layers Fig. 7. Aerobic mineralization of nitrogen was estimated from oxygen consumption using the mean measured $\mathrm{C} / \mathrm{N}$ ratio Table 2. For most stations, the budget obtained is not at steady state, with ammonium accumulation, but we need to consider that part of the tightly coupled nitrification-denitrification processes do not appear in our calculation, as well as ammonification and ammonium adsorption processes, which might explain a large part of the disequilibrium observed. These denitrification rates are low when compared with the range usually observed for various continental shelves as reviewed by Laursen and Seitzinger (2002). Another ap- proach to estimate denitrification is to consider surficial sediments as a black box, to calculate the nitrogen oxic regeneration from oxygen fluxes using appropriate stoichiometry, and to consider that the difference between nitrogen input (from oxic regeneration) and nitrogen releases (ammonium, nitrite and nitrate fluxes) might be attributed to denitrification processes (Devol et al., 1997). The resulting denitrification rates are in the range $0.26-0.60 \mathrm{mmol} \mathrm{N} \mathrm{m} \mathrm{d}^{-2}$, with lowest values at Stations $\mathrm{K}$ and $\mathrm{D}$, whereas higher rates are obtained in the western part of the area studied, with maximal values at Stations $L$ and $P$. The values obtained are an order of magnitude higher than the one calculated from pore-water profiles, and we hypothesize that the difference between those two calculations may be linked to tightly coupled nitrificationdenitrification processes that may reach $60-100 \%$ of total denitrification in continental shelf sediments (Laursen and Seitzinger, 2002). Moreover, the reoxidation of reduced compounds was not integrated into our calculations, and aerobic degradation should appear as a maximal value. Blackburn et al. (1990) previously showed that oxidation of ammonium, reduced iron, manganese or sulphide may play an important role in sediment oxygen uptake in this area. Globally, the functional scheme is similar to that described on continental shelves by Christensen et al. (1988) for the Eastern Mediterranean or Denis et al. (2001) in the Gulf of Lions. 


\subsubsection{Phosphate}

Phosphate fluxes were in the wide range of data earlier reported for the Gulf of Lions ( -0.336 to $0.072 \mathrm{mmol} \mathrm{m}^{-2}$ $\mathrm{d}^{-1}$, Blackburn and Lomstein, 1989), and predicted fluxes agreed reasonably well with measured fluxes (Fig. 6d). Nevertheless, benthic efflux of phosphate remains low, with maximal averaged values observed at Stations $\mathrm{G}$ and $\mathrm{H}$, in front of the Rhône river mouth. The comparison of averaged phosphate efflux with the hypothetical phosphate regenerated via the oxic mineralization (assuming a 138:1 ratio $\mathrm{O}_{2}: \mathrm{PO}_{4}{ }^{3-}$ ) evidences a mean overestimate by a factor of 3 . On the contrary, even if the ratio (DIN flux $/ \mathrm{PO}_{4}{ }^{3-}$ flux) shows large variability between the stations, the average ratio observed is 15.4 , very close to the expected Redfield ratio of 16 . Low phosphate exchanges could be the consequence of the redox-dependent retention and accumulation of phosphate by adsorption on $\mathrm{Fe}(\mathrm{III})$ oxyhydroxides, Fe-Mn phosphate complexes or adsorption onto carbonate surfaces (Ingall and Jahnke, 1993). This is in accord with the positive correlation between the predicted fluxes of ammonium and phosphate, as both showed a strong link with anaerobic mineralization processes.

\subsubsection{Silicate}

Silicate effluxes were globally in the same range as other measurements on the continental shelf in the Gulf of Lions, previously reported by Tahey et al. (1996), in the range of $0.744-1.416 \mathrm{mmol} \mathrm{m}^{-2} \mathrm{~d}^{-1}$ for two stations located, respectively, at depths of 80 and $60 \mathrm{~m}$. For stations located on the eastern part of the continental shelf $(\mathrm{C}, \mathrm{D}, \mathrm{G}$ and $\mathrm{H})$, silicate efflux was higher in June than in March, whereas a decrease was observed for western stations (L, P, S and T). Biogenic silica inputs on surficial sediments mainly originate from diatom frustules (Conley et al., 1988), undergoing dissolution processes that are more physically than biologically mediated, and varying with temperature and $\mathrm{pH}$. Dissolved silicate (DSi) accumulates in surficial sediments, and diffuses back towards the water column, again available for autotrophic organisms (Conley et al., 1993; Rahm et al., 1996). No evidence of major discrepancies in interstitial profiles of other nutrients may explain the spatial variations that we recorded, and water temperature varied in a very low range. Surprisingly, maximal silicate effluxes were not observed in front of the Rhône river, which could be expected, while considering that a major part of dissolved and biogenic silica might originate in the river (Conley et al., 1997). In the Gulf of Lions, the large discrepancy between eastern and western stations in March might be the consequence of the inputs from the Rhône River towards the west following the general circulation, hence stimulating phytoplankton productivity. For example, Turner and Rabalais (1994) demonstrated that in the Mississippi river delta, increased riverborne nutrient loads may explain the increasing deposition of biogenic silica, via the stimulation of phytoplankton growth
(Conley et al., 1993). Such a statement is not true any more in June, and may be linked to a lower river discharge, as well as the occurrence of a marine phytoplankton bloom between these sampling periods (Denis et al., 2001).

\subsection{Carbon and nutrient budgets for the continental shelf}

Considering a mean respiratory coefficient of 0.85 , the carbon remineralization processes reached 38.1-72.6 mgC $\mathrm{m}^{-2} \mathrm{~d}^{-1}$ in March and 39.6-90.2 $\mathrm{mgC} \mathrm{m}^{-2} \mathrm{~d}^{-1}$ in June. More accurate calculations of budgets were performed by interpolating data using the point kriging method. The average oxygen fluxes obtained with this interpolation method were 5.15 and $6.33 \mathrm{mmol} \mathrm{m}^{-2} \mathrm{~d}^{-1}$, respectively, in March and June, quite close to the mean values of all measurements (5.29 and $\left.6.11 \mathrm{mmol} \mathrm{m}^{-2} \mathrm{~d}^{-1}\right)$. This resulted in average mineralization processes of $52.6 \mathrm{mgC} \mathrm{m}^{-2} \mathrm{~d}^{-1}$ in March and $64.6 \mathrm{mgC} \mathrm{m}^{-2}$ $\mathrm{d}^{-1}$ in June. As earlier pointed out in the Gulf of Lions by Peinert et al. (1991), the particles settling after the development of a spring phytoplankton bloom could reach the bottom in $1 \mathrm{~d}$, and the vertical flux of OC during a phytoplankton bloom varied from 13 to $38 \mathrm{mgC} \mathrm{m} \mathrm{d}^{-2}$. Even if the sampling periods in early and late spring may have been characterized by a high primary productivity or a phytoplankton bloom, these calculations demonstrate the need for large lateral inputs to sustain the mineralization rates measured. While considering that the continental shelf (depth $<200 \mathrm{~m}$ ) area is about $16000 \mathrm{~km}^{2}$ (Marsaleix, 1993), respectively, 841 and 1033 tons of carbon are mineralized per day. On this basis, temporal extrapolation results in an annual mineralization of $342 \mathrm{kt} \mathrm{C}$. Comparison with an average primary productivity of $106 \mathrm{gC} \mathrm{m}^{-2} \mathrm{a}^{-1}$ as estimated by Morel and André (1991) shows that benthic remineralization is equivalent to $20 \%$ the OC primarily produced in the Gulf of Lions. Moreover, we need to consider that sedimentary mineralization rates presented here surely underestimate reality, as no measurement was performed in the direct vicinity of the Rhône River (Blackburn, 1993) or in coastal systems (Gulf of Fos: Grenz et al., 1991; Thau lagoon: Mazouni et al., 1996; Prevost lagoon: Bartoli et al., 1996), where previous studies logically report higher SOD. Moreover, including these earlier data in our budget should be avoided as these coastal systems are generally characterized by a large temporal and spatial variability (Wassmann et al., 1996), annual budget calculations consequently requiring a large database.

Similar budget calculations may be done for nutrients. For nitrogen, we estimated a mean release of $0.220 \mathrm{mmol} \mathrm{m}^{-2} \mathrm{~d}^{-1}$ DIN in March (0.035:0.2:-0.016 for $\mathrm{NH}_{4}{ }^{+}: \mathrm{NO}_{3}{ }^{-}: \mathrm{NO}_{2}{ }^{-}$) and 0.125 mmol m${ }^{-2} \mathrm{~d}^{-1}$ DIN (0.008:0.12:-0.004 for $\mathrm{NH}_{4}^{+} / \mathrm{NO}_{3}{ }^{-}$ $/ \mathrm{NO}_{2}{ }^{-}$) in June, equivalent to an annual release of $14.1 \mathrm{kt}$ DIN on the whole continental shelf. Phosphate release averaged $0.014 \mathrm{mmol} \mathrm{m}^{-2} \mathrm{~d}^{-1}$ in March and $0.017 \mathrm{mmol} \mathrm{m}^{-2} \mathrm{~d}^{-1}$ in June, equivalent to an annual efflux of $2.9 \mathrm{kt} P$, whereas for silicate, exchanges were always high (averaging $1.09 \mathrm{mmol}$ $\mathrm{m}^{-2} \mathrm{~d}^{-1}$ in March and $0.92 \mathrm{mmol} \mathrm{m}^{-2} \mathrm{~d}^{-1}$ in June) and resulted in an annual release around $165 \mathrm{kt}$ DSi. Considering 
Table 6

Comparison of average nutrient inputs in the Gulf of Lions via the Rhône river, the North Mediterranean Current, and continental shelf sediments, versus nutrient requirement for primary productivity $\left({ }^{*}\right.$ only nitrate inputs, nd: no data)

\begin{tabular}{lllll}
\hline & Inputs $\left(\mathrm{kt} \mathrm{a}^{-1}\right)$ & & & Consumption $\left(\mathrm{kt} \mathrm{a}^{-1}\right)$ by primary productivity \\
& Rhone river & North Mediterranean Current & Continental shelf sediments & \\
\hline DIN & $99.9-104.3$ & $75^{*}$ & 14.1 & 299 \\
DIP & $2.7-3$ & 6 & 2.9 & 41 \\
DSi & $135-139$ & nd & 165 & 600 \\
References & Moutin et al. (1998) & Conan (1996) & This study & Morel and André (1991) \\
\hline
\end{tabular}

the whole continental shelf system in the Gulf of Lions, sediment-water exchanges of nutrients were compared with others inputs (Table 6) originating from the Rhône river (Moutin et al., 1998) and the North Mediterranean Current (Conan, 1996) as well as requirements for primary productivity (Morel and André, 1991). We thereby demonstrate that silicate and phosphate inputs from sediments are equivalent to the inputs from the Rhone River, and may respectively, account for $7 \%$ and $25.7 \%$ of the requirements for primary production. Nitrogen inputs from the sediments represent a lower part of the nitrogen demand for primary production (4.7\%) but are still equivalent to $14 \%$ DIN inputs from the Rhone River. Consequently, sediments appear to play a significant role in the biogeochemical cycles on the Gulf of Lion's continental shelf.

It was previously stated that temporal variability in sediment-water exchanges should be taken into account in this area for an accurate estimate of DIN fluxes (Denis et al., 2001), but integrating such variability at mesoscale seems difficult unless a large database is previously established. A means to achieve this aim might be the use of a diagenetic model, coupled with numerous spatial and temporal measurements. Nevertheless, our results, considered as two timefixed 'pictures' of sediment-water exchanges, demonstrate the wide influence of surficial sediments in biogeochemical cycles and the need to take these fluxes into account for future budget calculations in the Gulf of Lions. A next step might be to integrate these results into a coupled hydrodynamic-biogeochemical pelagic model, to estimate the role of benthic nutrient regeneration on primary productivity in the Gulf of Lions.

\section{Acknowledgements}

This study took place in the frame of the National Program in Coastal Environment (PNEC) through the Moogli 1 and Moogli 2 cruises. We thank captains, officers and crew of the $\mathrm{R} / \mathrm{V}$ L'Atalante and Le Suroit who largely participated in the success of this study. We are also indebted to E. Alliot and V. Jones for their help during sampling and analysis, onboard and in the laboratory. We also wish to thank two anonymous reviewers for comprehensive comments and constructive suggestions.

\section{References}

Bartoli, M., Cattadori, M., Giordani, G., Viaroli, P., 1996. Benthic oxygen respiration, ammonium and phosphorus regeneration in surficial sediments of the Sacca Di Goro (Nothern Italy) and two French coastal lagoons: a comparative study. Hydrobiologia 329, 143-159.

Bertuzzi, A., Faganeli, J., Brambati, A., 1996. Annual variations of benthic nutrient fluxes in shallow coastal waters (Gulf of Trieste, Northern Adriatic Sea). P.S.Z.N. I: Mar. Ecol. 17, 261-278.

Blackburn, T.H., 1991. Mineralization in northwestern Mediterranean Sea sediments: Cybele cruise. In: Martin, J.M., Barth, H. (Eds.), Water Pollution Research Report 28-EROS 2000, Third Project Workshop, Den Burg/Texel, The Netherlands. CEC Directorate General for Science, Research and Development, Brussels. pp. 469-479.

Blackburn, T.H., 1993. Nitrogen cycling in NW Mediterranean sediments. In: Martin, J.M., Barth, H. (Eds.), Water Pollution Research Report 30-EROS 2000, Fourth Project Workshop, Plymouth, UK. CEC Directorate General for Science, Research and Development, Brussels. pp. 225-229.

Blackburn, T.H., Lomstein, B.A., 1989. Carbon and nitrogen mineralization in Gulf of Lions sediments. In: Martin, J.M., Barth, H. (Eds.), Water Pollution Research Report 13-EROS 2000, First Project Workshop, Paris, France. CEC Directorate General for Science, Research and Development, Brussels. pp. 561-576.

Blackburn, T.H., Lund, E., Lomstein, B.A., 1990. Bacterial processes in sediments. In: Martin, J.M., Barth, H. (Eds.), Water Pollution Research Report 20-EROS 2000, Second Project Workshop, Blanes, Spain. CEC Directorate General for Science, Research and Development, Brussels. pp. 561-576.

Boudreau, B.P., 1997. Diagenetic Models and their Implementation. Springer Verlag, Berlin $415 \mathrm{p}$.

Buscail, R., Germain, C., 1997. Present-day organic matter sedimentation on the NW Mediterranean margin: importance of off-shore export. Limnol. Oceanogr. 42, 217-229.

Chassefiere, B., 1990. Mass-physical properties of surficial sediments on the Rhône continental margin: implications for the nepheloid benthic layer. Cont. Shelf Res. 10, 857-867.

Christensen, J.P., Devol, A.H., Smethie, W.M., 1984. Biological enhancement of solute exchange between sediments and bottom water on the Washington continental shelf. Cont. Shelf Res. 3, 9-23.

Christensen, J.P., Goldsmith, V., Walline, P., Schneller, A., El Sayed, S.Z., 1988. Sedimentary nutrient regeneration on the oligotrophic Eastern Mediterranean continental shelf. Océanographie pélagique méditerranéenne. In: Minas, H.J., Nival, P. (Eds.), Oceanol. Acta NºSP, pp. 219234.

Conan, P., 1996. Variabilité et bilan de la production primaire en zone côtière (Méditerranée nord-occidentale; entrée du golfe du Lion) en relation avec les systèmes biologique, chimique et hydrodynamique (Courant Nord Méditerranéen). Thèse de Doctorat, Université de la Méditerranée, Aix-Marseille.

Conley, D.J., Quigley, M.A., Schelske, C.L., 1988. Silica and phosphorus flux from sediments: importance of internal recycling in Lake Michigan. Can. J. Fish. Aquat. Sci. 45, 1030-1035. 
Conley, D.J., Schelske, C.L., Stoermer, E.F., 1993. Modification of the biogeochemical cycle of silica with eutrophication. Mar. Ecol. Prog. Ser. 101, 179-192.

Conley, D.J., Stockenberg, A., Carman, R., Johnston, R.W., Rahm, L., Wulff, F., 1997. Sediment-water nutrient fluxes in the Gulf of Finland. Baltic Sea. Estuar. Coast. Shelf Sci. 45, 591-598.

Cowan, J.L.W., Boynton, W.R., 1996. Sediment-water oxygen and nutrient exchanges along the longitudinal axis of Chesapeake Bay: seasonal patterns, controlling factors and ecological significance. Estuaries 19, 562-580.

Cowan, J.L.W., Pennock, J.R., Boynton, W.R., 1996. Seasonal and interannual patterns of sediment-water nutrient and oxygen fluxes in Mobile Bay, Alabama (USA): regulating factors and ecological significance. Mar. Ecol. Prog. Ser. 141, 229-245.

Denis, L., 1999. Dynamique des flux d'oxygène et de sels nutritifs à l'interface eau-sédiment sur la marge continentale du golfe du Lion (Méditerranée Nord-Occidentale). Thèse de Doctorat, Université de la Méditerranée, Aix-Marseille.

Denis, L., Grenz, C., Alliot, E., Rodier, M., 2001. Temporal variability in dissolved inorganic nitrogen fluxes at the sediment-water interface and related annual budget on a continental shelf (NW Mediterranean. Oceanol. Acta 24, 85-97.

Devol, A.H., Codispoti, L.A., Christensen, J.P., 1997. Summer and winter denitrification rates in western Arctic shelf sediments. Cont. Shelf Res. 17, 1029-1050.

Diaz, F., Raimbault, P., Boudjellal, B., Garcia, N., Moutin, T., 2001. Early spring phosphorus limitation of primary productivity in a NW Mediterranean coastal zone (Gulf of Lions. Mar. Ecol. Prog. Ser. 211, 51-62.

Durrieu de Madron, X., Radakovitch, O., Heussner, S., Loye-Pilot, M.D., Monaco, A., 1999. Role of the climatological and current variability on shelf-slope exchanges of particulate matter: evidence from the Rhône continental margin (NW Mediterranean. Deep-Sea Res. 46, 1513-1538.

Got, H., Aloisi, J.C., 1990. The Holocene sedimentation on the Gulf of Lions margin: a quantitative approach. Cont. Shelf Res. 10, 841-855.

Grenz, C., Plante-Cuny, M.R., Plante, R., Alliot, E., Baudinet, D., Berland, B., 1991. Measurement of benthic nutrient fluxes in Mediterranean shellfish farms: a methodological approach. Oceanol. Acta 14, 195-201.

Ingall, E., Jahnke, R., 1993. Evidence for enhanced phosphorus regeneration from marine sediments overlaid by oxygen depleted waters. Geochim. Cosmochim. Acta 58, 2571-2575.

Koop, K., Boynton, W.R., Wulff, F., Carman, R., 1990. Sediment-water oxygen and nutrient exchanges along a depth gradient in the Baltic Sea. Mar. Ecol. Prog. Ser. 63, 65-77.

Laursen, A.E., Seitzinger, S.P., 2002. The role of denitrification in nitrogen removal and carbon mineralization in Mid-Atlantic Bight sediments. Cont. Shelf Res. 22, 1397-1416.

Leveau, M., Coste, B., 1987. Impacts des apports rhodaniens sur le milieu pélagique du golfe du Lion. Bull. Ecol. 18, 119-122.

Lohse, L., Epping, E.H.G., Helder, W., Van Raaphorst, W., 1996. Oxygen pore water profiles in continental shelf sediments of the North Sea: turbulent versus molecular diffusion. Mar. Ecol. Prog. Ser. 145, 63-75.

Marsaleix, P., 1993. Modélisation tridimensionnelle de la circulation océanique dans le golfe du Lion. Thèse de Doctorat, Université P. Sabatier, Toulouse.

Martin, J.M., Milliman, J.D., 1997. EROS 2000 (European River Ocean System). The western Mediterranean: an introduction. Deep-Sea Res. 44, 521-529.

Mazouni, N., Gaertner, J.C., Deslous-Paoli, J.M., Landrein, S., Geringer d'Oedenberg, M., 1996. Nutrient and oxygen exchanges at the sediment water interface in a shellfish farming lagoon (Thau, France). J. Exp. Mar. Biol. Ecol. 205, 91-113.

Middelburg, J.J., Soetaert, K., Herman, P.M.J., 1997. Empirical relationships for use in global diagenetic models. Deep-Sea Res. 44, 327-344.
Millot, C., 1987. Circulation in the western Mediterranean Sea. Oceanol. Acta 10, 143-149.

Millot, C., 1990. The Gulf of Lion's hydrodynamics. Cont. Shelf Res. 10, 885-894.

Monaco, A., Biscaye, P.E., Soyer, J., Pocklington, R., Heussner, S., 1990. Particle fluxes and ecosystem response on a continental margin: the 1985-1988 Mediterranean ECOMARGE experiment. Cont. Shelf Res. $10,809-841$.

Morel, A., André, J.M., 1991. Pigment distribution and primary production in the western Mediterranean as derived and modeled from coastal zone scanner observations. J. Geophys. Res. 96, 12685-12698.

Morel, A., Bricaud, A., ré, J.M., Pelaez-Hudlet, J., 1990. Spatial-temporal evolution of the Rhône river plume as seen by CZCS imagery: consequences upon primary production in the Gulf of Lions. In: Martin, J.M., Barth, H. (Eds.), Water Pollution Research Report 20-EROS 2000, Second Project Workshop, Blanes, Spain. CEC Directorate General for Science, Research and Development, Brussels. pp. 45-62.

Moutin, T., Raimbault, P., Golterman, H.L., Coste, B., 1998. The input of nutrients by the Rhône river into the Mediterranean Sea: recent observations and comparison with earlier data. Hydrobiologia 373/374, 237246.

Peinert, R.D., Fowler, S.W., La Rosa, J., Miquel, J.C., Teyssie, J.L., 1991. Vertical flux and microplankton assemblages in the Gulf of Lions during spring 1990. In: Martin, J.M., Barth, H. (Eds.), Water Pollution Research Report 28-EROS 2000, Third Project Workshop, Den Burg/Texel, The Netherlands. CEC Directorate General for Science, Research and Development, Brussels. pp. 413-424.

Pinazo, C., Marsaleix, P., Millet, B., Estournel, C., Véhil, R., 1996. Spatial and temporal variability of phytoplankton biomass in upwelling areas of the northwestern Mediterranean: a coupled physical and biogeochemical modelling approach. J. Mar. Syst. 7, 161-191.

Pinazo, C., Marsaleix, P., Millet, B., Estournel, C., Kondrachoff, V., Véhil, R., 2001. Phytoplankton variability in summer in the northwestern Mediterranean: modelling of the wind and freshwater impacts. J. Coast. Res. 17, 146-161.

Rahm, L., Conley, D.J., Sanden, P., Wulff, F., Stalnacke, P., 1996. Time series analysis of nutrient inputs to the Baltic Sea and changing DSi/DIN ratio. Mar. Ecol. Prog. Ser. 130, 221-228.

Scherrer, B., 1984. Biostatistique. Gaëtan Morin éditeur, Chicoutimi 850 p.

Solorzano, L., 1969. Determination of ammonia in natural waters by the phenolhypochlorite method. Limnol. Oceanogr. 14, 799-801.

Strickland, J.D.H., Parsons, T.R., 1972. A Practical Handbook of Seawater Analysis. Fisheries Research Board Canada, Bulletin 167, 311 p.

Tahey, T.M., Duineveld, G.C.A., Berghuis, E.M., Helder, W., 1994. Relation between sediment-water fluxes of oxygen and silicate and faunal abundance at continental shelf, slope and deep water stations in the Northwest Mediterranean. Mar. Ecol. Prog. Ser. 104, 119-130.

Tahey, T.M., Duineveld, G.C.A., De Wilde, P.A.W.J., Berghuis, E.M., Kok, A., 1996. Sediment $\mathrm{O}_{2}$ demand, density and biomass of the benthos and phytopigments along the northwestern Adriatic coast: the extent of Po enrichment. Oceanol. Acta 19, 117-130.

Tréguer, P., Le Corre, P., 1975. Manuel d'Analyse des Sels nutritifs dans l'Eau de Mer : Utilisation de l'Autoanalyseur II Technicon. Université de Bretagne Occidentale, Brest.

Turner, R.E., Rabalais, N.N., 1994. Coastal eutrophication near the Mississippi river delta. Nature 368, 619-621.

Tusseau-Vuillemin, M.H., Mortier, L., Herbaut, C., 1998. Modeling nitrate fluxes in an open coastal environment (Gulf of Lions): transport versus biogeochemical processes. J. Geophys. Res. 103, 7693-7708.

Ullman, W.J., Aller, R.C., 1982. Diffusion coefficients in nearshore marine sediments. Limnol. Oceanogr. 27, 552-556. 
Walsh, J.J., 1991. Importance of continental margins in the marine biogeochemical cycling of carbon and nitrogen. Nature 350, 53-55.

Wassmann, P., reassen, I., Reigstad, M., Slagstad, D., 1996. Pelagic-benthic coupling in the Nordic sea: the role of episodic events. P.S.Z.N. I: Mar. Ecol. 17, 447-471.
Zuo, Z., Eisma, D., Gieles, R., 1993. Effect of particle transport and mixing on ${ }^{210} \mathrm{~Pb}$ distribution in the northwestern Mediterranean Sea. In: Martin, J.M., Barth, H. (Eds.), Water Pollution Research Report 28-EROS 2000, Fourth Project Workshop, Plymouth, UK. CEC Directorate General for Science, Research and Development, Brussels. pp. 425-436. 